Please do not remove this page

RMIT

UNIVERSITY

\title{
Investigating the levels and trends of organochlorine pesticides and polychlorinated biphenyl in sewage sludge
}

Clarke, Bradley; Porter, Nichola; Marriott, Philip; Blackbeard, Judy

https://researchrepository.rmit.edu.au/esploro/outputs/9921857851301341/filesAndLinks?institution=61RMIT_INST\&index=null

Clarke, B., Porter, N., Marriott, P., \& Blackbeard, J. (2010). Investigating the levels and trends of organochlorine pesticides and polychlorinated biphenyl in sewage sludge. Environment International, 36(4), 323-329. https://doi.org/10.1016/j.envint.2010.01.004

Published Version: https://doi.org/10.1016/j.envint.2010.01.004

Repository homepage: https://researchrepository.rmit.edu.au

(c) 2010 Elsevier Ltd. All rights reserved.

Downloaded On 2023/04/27 00:35:22 +1000 
Investigating the levels and trends of organochlorine pesticides and polychlorinated biphenyl in sewage sludge

3 Bradley O. Clarke ${ }^{1,2, *}$, Nichola A. Porter ${ }^{1,2}$, Philip J. Marriott ${ }^{1}$ \& Judy R. Blackbeard ${ }^{2}$

$4 \quad{ }^{1}$ School of Applied Sciences, RMIT University, Melbourne, Australia.

$5 \quad{ }^{2}$ Water Quality Research Australia, Adelaide, Australia (formerly Co-operative

6 Research Centre for Water Quality and Treatment - Wastewater Program, Melbourne,

7 Australia).

$8 *$ Corresponding Author

9 RMIT University

10 School of Applied Science (Bld 3 Level 1)

$11 \quad$ Fax +61399253747

$12 \quad$ Phone +61399251787

13 brad.clarke.aus@gmail.com

\section{KEYWORDS}

15 OCPs, sewage sludge, DDT, dieldrin, chlordane, biosolids, PCBs, carcinogen

\section{ABBREVIATION}

17 DDD - 1,1-dichloro-2,2-bis( $p$-chloro- phenyl)ethane; DDE - 1,1-dichloro-2,2-bis( $p$ -

18 chlorophenyl)ethylene; DL - Detection limit; DDT - 1,1,1-trichloro-2,2-bis( $p$ -

19 chlorophenyl)ethane; DS - Dry solids; HCB - Hexachlorobenzene; HCH -

20 Hexachlorohexane; LOD - Limit of detection; OCPs - Organochlorine pesticides;

21 PCBs - Polychlorinated biphenyls; WWTP - Wastewater treatment plant 


\section{ABSTRACT}

25 A study was completed to investigate temporal trends of organochlorine pesticides

26 (OCPs; aldrin, chlordane, dieldrin, heptachlor, hexachlorbenzene, DDT) and polychlorinated biphenyls (PCBs) in sewage sludge. Between 2004 and 2006 the concentration of OCPs and PCBs in Australian sewage sludge $(n=829)$ was consistently $<1 \mathrm{mg} \mathrm{kg}^{-1}$ dry solids DS. Dieldrin, chlordane and DDE were detected in $68 \%, 27 \%$ and $13 \%$ at maximum concentrations of $0.77,0.29$ and $0.27 \mathrm{mg} \mathrm{kg}^{-1} \mathrm{DS}$,

31 respectively.

32 Time series analysis (1995-2006) of OCPs and PCBs sewage sludge concentrations (n

33 = 2266) taken from six wastewater treatment plants (WWTPs) of the same geographic 34 region found that lindane, aldrin $\mathrm{HCB}$, heptachlor, DDT, DDD and PCBs were 35 infrequently detected $(<8 \%)$. A correlation between dieldrin and chlordane levels was 36 found $(\mathrm{P}<0.05)$ which provides evidence of similar environmental mechanisms 37 facilitating movement of dieldrin and chlordane through environment compartments.

38 It has taken more than 10 years for dieldrin and chlordane to reduce to less than 39 detectable concentrations in freshly generated sewage sludge in Australia following 40 government restrictions.

41 Internationally, reported sewage sludge OCP concentrations were consistently low 42 and often less than detection limits. Therefore, OCPs are not considered to be a 43 contaminant of regulatory concern for countries that phased out OCP use several 44 decades ago. Concentrations of PCBs in sewage sludge were also consistently low 45 and rarely exceeded European contaminant limits and therefore, regulatory limits may warrant review. The authors recommend that Australian authorities revise regulatory requirements for OCP and PCBs contaminant levels in sewage sludge destined for beneficial reuse as biosolids. 
51 Many countries have contaminant limits for organic pollutants in biosolids (treated

52 sewage sludge) to assess its suitability for beneficial recycling (i.e. applied to land as

53 a fertilizer). Internationally, Australia is the only country to have contaminant limits

54 for organochlorine pesticides (OCPs), which may be a consequence of a relative

55 recent phasing out of these compounds in the 1990s. Many third-world countries

56 continue to use OCPs for malaria control and this study will provide information

57 regarding the expected length time that environmental contamination will occur.

58 Similar to Australia, a number of European countries have contaminant limits for

59 polychlorinated biphenyls (PCBs), therefore studies of PCBs in sewage sludge are

60 internationally relevant (European Commission, 2001). Regardless of whether

61 sewage sludge in beneficially recycled, it is an important environmental matrix to

62 monitor for organic chemical pollution.

63 OCPs are considered to be the second generation of pesticides that took over from the

64 early first generation of insecticides produced from inorganic compounds (arsenic,

65 lead, copper, sulfur) in the 1940s (Chenier, 2002). The use of these chemicals

66 improved our quality of life by ensuring a regular supply food, as well as protection

67 against insect borne disease. The most infamous OCP, DDT (1,1,1-trichloro-2,2-

68 bis( $p$-chlorophenyl)ethane), was found to be remarkably active against a number of

69 insect pests. Ironically, one of the valued properties of DDT was its persistence,

70 reducing the need for frequent applications. DDT became the prototype OCP from

71 which other more toxic pesticides where developed viz. aldrin, dieldrin, lindane,

72 chlordane and heptachlor. Due to the persistence of many OCPs and their potential

73 impact upon human and wildlife health (as carcinogens and endocrine disruptors),

74 international treaties have been developed to prevent further environmental

75 contamination. Despite restrictions for use in most Western nations, OCPs and their

76 breakdown products are still detected in many environmental compartments,

77 including humans, throughout the world (Erickson, 1997; Zitko, 2003; Harden et al., 78 2005).

79 PCBs are one of the great environmental pollutants of the twentieth century. The 80 commercial production of PCBs began in the USA in 1929 and their commercially

81 valued properties were electrical resistance, low volatility and resistance to 
degradation at high temperatures. The commercial product(s) were a complex mixture of PCB isomers and used for a variety of purposes, such as dielectric fluids in capacitors and transformers. It was not until the 1960s that PCBs were found to accumulate in biota globally, entering the food chain through "the backdoor" (Jensen, 1972). Due to their persistence and potential impact on humans and wildlife (carcinogens, endocrine disruptors) in 2001 they were included in the Stockholm Convention on Persistent Organic Pollutants to prevent further environmental contamination (UNEP, 2001). Even though PCB production has been banned in most countries since the 1970s and 1980s, they are still found in infrastructure throughout the world. It is estimated that over 1 million tonnes of PCBs have been generated and about one third of this quantity is thought to be continuing to circulate in the environment (Birkett, 2003). PCBs are now ubiquitous environmental pollutants, occurring in human and animal tissue, and most environmental compartments (Erickson, 1997).

This paper presents a literature review of OCPs and PCBs in sewage sludge, detailing the typical concentrations and trends observed internationally. This review is pertinent to countries that have regulatory limits for PCBs in sewage sludge (viz., Australia, Germany) and other countries considering such restrictions (European Commission, 2001). This is followed by data obtained from two Australian monitoring studies that have quantified levels and trends of OCPs and PCBs in Australian sewage sludge and compares them to domestic guidelines and international studies.

\section{METHODOLGY}

\subsection{Historical Levels and Sources}

A comprehensive examination of the scientific peer-reviewed literature is presented that examines OCPs and PCBs sewage sludge concentrations and sources.

\subsection{Australian Sewage Sludge Survey 2004 - 2006}

Australian WWTPs must monitor sewage sludge intended for beneficial reuse for OCPs and PCBs. Concentration data $(n=829)$ was obtained from participating WWTPs $(n=58)$ that was released to the authors on condition of anonymity. Results are discussed at an aggregate level, organised according to State and year (Table 1). 
113 To ensure comparable data, only freshly generated sewage sludge samples (2004 -

114 2006) analysed at National Association of Testing Association (NATA) accredited

115 laboratories have been included.

116 2.3. Australian sewage sludge time series - 1995 to 2006

117 A time series analysis of OCP and PCBs concentrations in sewage sludge from five

118 Australian WWTPs between 1995 - 2006, and one WWTP between 2001 and 2004,

119 all from the same geographic region and analysed approximately weekly is presented.

120 All data were generated from the same NATA accredited laboratory and the detection

121 limit was reduced simultaneously in 2001 from $0.1 \mathrm{mg} \mathrm{kg}^{-1}$ dry solids (DS) to $0.01 \mathrm{mg}$

$122 \mathrm{~kg}^{-1} \mathrm{DS}$.

\section{RESULTS AND DISCUSSION}

\subsection{Historical Levels and Sources}

\subsubsection{Organochlorine Pesticides}

126 A large volume of research investigating OCPs in environmental compartments has

127 been published; however, few studies of levels and trends in sewage sludge have been

128 published. There has been no review undertaken on this subject internationally and in

129 Australia, no published research could be found. The concentration of OCPs in

130 sewage sludge has been reported from the USA, the UK, Sweden, Italy, Greece and

131 recently, China. A summary of English language peer-reviewed articles about OCPs

132 in sewage sludge is presented in Table 1.

133 McIntyre et al. (1982) was one of the first researchers to report the concentrations of

134 DDE, dieldrin and lindane in UK sewage sludges $(n=40)$. DDE was detected in all

135 samples (0.01 - $0.49 \mathrm{mg} \mathrm{kg}^{-1} \mathrm{DS}$; mean 0.04), but dieldrin and lindane were not. The

136 maximum concentrations of dieldrin and lindane were slightly higher than the

137 maximum DDE concentration; dieldrin $<0.01-1.26 \mathrm{mg} \mathrm{kg}^{-1} \mathrm{DS}$, lindane $<0.01-0.93$

$138 \mathrm{mg} \mathrm{kg}^{-1} \mathrm{DS}$ (McIntyre \& Lester, 1982). McIntyre et al. (1984) continued this work,

139 reporting the concentration of lindane, aldrin, dieldrin and endrin from a survey of

140444 UK sewage sludges. The omission of DDE appears to be an unusual omission,

141 given that DDE was detected in all samples in the earlier survey. The major

142 pesticides detected were lindane and dieldrin and the maximum concentrations were

143 far higher than the previous study: 70.00 and $52.94 \mathrm{mg} \mathrm{kg}^{-1}$ DS respectively. These 
144 maximum concentrations were unusual as the mean and median concentrations are

145 more representative of the typical concentrations of UK sludges at the time; median

146 concentration 0.09 and $0.13 \mathrm{mg} \mathrm{kg}^{-1}$ DS respectively (McIntyre \& Lester, 1984).

147 The nineties saw the improvement in analytical techniques and improved detection

148 limits, which was required due to the decreasing concentrations of most OCPs in

149 sewage sludge. The detection of OCPs was still common in Swedish, Italian and

150 Canadian sludges. In a study of OCPs in Swedish sludge samples, Total DDT, HCB

151 and lindane were detected, albeit at low concentrations $<0.1 \mathrm{mg} \mathrm{kg}^{-1}$ DS (Nylund et

$152 a l ., 1992)$. HCB and DDE, were detected in Italian sludges $(\mathrm{n}=5)$ at concentrations

153 ranging from 0.01 to $0.31 \mathrm{mg} \mathrm{kg}^{-1} \mathrm{DS}$ and $0.02-0.09 \mathrm{mg} \mathrm{kg}^{-1} \mathrm{DS}$ (Ottaviani et al.,

154 1993). DDT and DDD were also detected but interfering analytes prevented the

155 quantification of these compounds. A survey of Canadian sludges in 1996 found that

156 aldrin, chlordane, heptachlor and DDT were below the survey detection limit $(<0.01$

$\left.157 \mathrm{mg} \mathrm{kg}^{-1} \mathrm{DS}\right)$. DDE and HCB were detected, but they weren't detected in all samples

158 (median concentration less than detection limit) with concentrations ranging from

$159<0.01$ to $0.013 \mathrm{mg} \mathrm{kg}^{-1} \mathrm{DS}$ and $<0.01-0.033 \mathrm{mg} \mathrm{kg}^{-1} \mathrm{DS}$ respectively (Webber et al.,

160 1996). This sampling event was approximately fifteen years after Canada phased out

161 these compounds, which may provide an indication of the time required for a nation's

162 sewage sludges and environment to undergo natural processes of depuration.

163 By the new millennium, the detection of OCPs in sewage sludge was becoming less

164 common, with some researchers choosing not to monitor for OCPs in national surveys

165 of organic pollutants in sewage sludge (Bright \& Healey, 2003). In an analysis of

166 digested sludge from fourteen UK WWTPs HCHs, HCB, endosulfan, DDT, DDD,

167 DDE and chlordane were often below the detectable limit (Stevens et al., 2003). The

168 concentration of two of the compounds above the detection limit were: HCB (median

$16922 \mu \mathrm{g} \mathrm{kg}^{-1} \mathrm{DS}$ ) and DDE (median $13 \mu \mathrm{g} \mathrm{kg}^{-1} \mathrm{DS}$ ) (Stevens et al., 2003). This

170 observation is consistent with declining use of OCPs in Europe. HCB, like other

171 chlorobenzenes, has some industrial applications, which may account for its

172 continuing presence in all the samples. It is also relatively volatile and ubiquitous in

173 the atmosphere (Stevens et al., 2003).

174 The latest report of sludge samples analysed for OCPs (HCH, DDT, DDD, DDE and 175 BHC) came from data collected in 2005 from 31 WWTPs in 26 cities of China. 
176 Concentrations of HCHs (all four isomers) were not regularly detected and the median

177 concentration was <LOD for all isomers. The presence of DDTs was detected

178 frequently. The detection of DDT suggests that DDT is still currently being used

179 within China; however, DDT is a contaminant in other pesticides such as diclofol,

180 which may have been a source and is still used in China. HCB was detected in all

181 sludge samples (range: 7.5 to $319 \mu \mathrm{g} \mathrm{kg}^{-1} \mathrm{DS}$ ). The source of this compounds has

182 been associated with the production of pentachloronitrobenzene and linked to

183 combustion and metallurgical processes involving the use of chlorine (Wang et al.,

184 2007).

185 The concentration of OCPs has been decreasing in countries where government

186 restrictions have been applied. DDE, dieldrin and lindane are the most commonly

187 detected OCPs. While most OCPs appear to be below current detection limits in

188 sludges, DDE and dieldrin appear to have a much longer half-life since they are still

189 regularly detected fifteen years after being banned.

190 TABLE 1 NEAR HERE

191 A major difference in sewerage systems between nations can be the incorporation of

192 stormwater drains. In countries such as Australia, the sewer system is closed.

193 Therefore, the movement of OCPs directly into the sewerage system is less likely than

194 European systems that also catch and treat rain water. OCPs may enter the WWTP

195 process from industrial discharge or as a component of urban runoff or drainage into

196 the system. However, little research has been carried out to investigate the

197 environmental pathways and source of these compounds in sludge. The most

198 illuminating work was a study by Nylund et al. (1992) that measured the

199 concentration of organic contaminants in sewage sludge during a dry and rainy

200 period. They found that the concentrations of DDT increased from $39 \mu \mathrm{g} \mathrm{kg}^{-1} \mathrm{DS}$ in a

201 dry period to $68 \mu \mathrm{g} \mathrm{kg}^{-1} \mathrm{DS}$ in a wet period and suggested that atmospheric deposition

202 facilitates the movement of this pesticide to the WWTP. This suggests that a

203 significant portion of DDTs are either washed out of the atmosphere with rain or the

204 rainfall washes out pesticide residues from the urban environment, or perhaps a

205 combination of both. Determining if DDT was washed out of the atmosphere would

206 be relatively easy by measuring DDT concentrations in rainfall. The concentration of

207 lindane was not significantly different between the two periods $\left(8.7\right.$ and $7.8 \mu \mathrm{g} \mathrm{kg}^{-1}$ 
208 DS respectively), which suggests that precipitation does not play major role in the 209 movement of lindane. Oddly, the concentration of HCB decreased from 43 to $11 \mu \mathrm{g}$

$210 \mathrm{~kg}^{-1}$ DS from the dry to the wet period. No explanation of this phenomenon was

211 provided but the most likely explanation is dilution.

212 Various studies have investigated the fate of OCPs within a WWTP. While most

213 OCPs are persistent (Buisson et al., 1986) it was reported that lindane can be

214 effectively removed by wastewater treatment, with reductions of $67 \pm 10 \%$

215 (Kipopoulou et al., 2004). Lindane is more water-soluble compared to other OCPs

216 and therefore more biodegradable. Lindane also has a higher vapour pressure so

217 could be volatilised particularly in an aeration basin of an activated sludge WWTP.

218 3.1.2. Polychlorinated Biphenyls

219 Much work has been conducted into the concentrations of PCBs in sewage sludge,

220 with research published from the United States of America (USA), the United

221 Kingdom (UK), the Netherlands, Italy, Switzerland, Canada, Ireland, Greece and

222 Spain. The majority of this research was directed towards understanding the risk

223 posed by the land application of sewage sludge, as well as quantifying the

224 environmental release of PCBs in sludge and wastewaters. However, a direct of

225 comparison of all data is confounded by the different reporting styles. There are a

226 total of 209 individual PCBs and quantification of all 209 is generally not possible or

227 necessary. Concentrations were originally reported in terms of the commercial

228 formulation, Arochlors ${ }^{\mathrm{TM}}$. Later, individual isomers were selected as representative

229 of $\Sigma \mathrm{PCB}$ concentration. In this review, the number of isomers included in the total

230 sum of PCBs will be included in brackets, i.e. $\Sigma$ PCBs (X).

231 One of the first reports of PCBs in sludge was of six USA sewage sludges (Bergh \&

232 Peoples, 1977). The concentrations are high when compared to other reported sludge

233 PCB levels, with a mean concentration of $765,000 \mu \mathrm{g} \mathrm{kg}^{-1} \mathrm{DS}$, ranging between

$234238,000-1,700,000 \mu \mathrm{g} \mathrm{kg}^{-1} \mathrm{DS}$. At this time in the USA, PCBs were still commonly

235 used and it is possible that reported concentrations were typical of sewage sludge of

236 that period or more likely, that PCB production or industries utilising PCBs were

237 located in the catchment. Another early study of PCBs sludge concentration from the

238 USA reported significantly lower concentrations that were still slightly higher than

239 modern samples (mean 5,200 $\mathrm{g} \mathrm{kg}^{-1} \mathrm{DS}$, range $<10$ to $23,000 \mu \mathrm{g} \mathrm{kg}{ }^{-1} \mathrm{DS}$ ). These 
240 concentration may be more indicative of PCB contaminant levels while it was still

241 unrestricted (Furr et al., 1976). Further studies of PCBs levels in USA sludges were

242 far lower than the earlier Bergh et al. (1977) study, with concentrations ranging

243 between 1,200 - 6,200 $\mu \mathrm{g} \mathrm{kg}^{-1}$ DS (West \& Hatcher, 1980) and $150-3,600 \mu \mathrm{g} \mathrm{kg}^{-1}$

244 DS (Mumma et al., 1984).

245 UK research reported concentrations of up 22,000 $\mu \mathrm{g} \mathrm{kg}^{-1} \mathrm{DS}$ (McIntyre \& Lester,

246 1984) which wasn't typical, as the mean concentrations were less than $1,000 \mu \mathrm{g} \mathrm{kg}^{-1}$

247 in two other separate UK sludge surveys (McIntyre \& Lester, 1982; McIntyre \&

248 Lester, 1984), which again may be associated with PCB productions or industrial uses

249 in the catchment. Concentrations of PCBs in sludges from the Netherlands were in a

250 similar range to the UK: $\Sigma$ PCBs (17) ranging from $390-1,480 \mu \mathrm{g} \mathrm{kg}^{-1} \mathrm{DS}$, mean 880

$251 \mu \mathrm{g} \mathrm{kg}^{-1} \mathrm{DS}$. The concentrations of PCBs in sludges in the 1980s were typically in the

252 low parts-per-million range, which was already far lower than the concentrations

253 reported in the 1970s by Bergh et al. (1977).

254 In the 1990s, the concentrations of PCB in sludges were declining and often below

$2551,000 \mu \mathrm{g} \mathrm{kg}^{-1} \mathrm{DS}$. For example, Italian sludges analysed in the early nineties had

256 PCB concentrations between 210 and $1010 \mu \mathrm{g} \mathrm{kg}^{-1}$ DS (Ottaviani et al., 1993). In a

257 follow up survey in the UK the total PCBs concentrations ranged between $110-440$

$258 \mu \mathrm{g} \mathrm{kg}^{-1} \mathrm{DS}$, which is similar to the concentrations reported by McIntrye et al. (1984)

259 and later in the Nineties by Alcock et al. (1993). This work was continued in 2003

260 when Stevens et al. reported the concentration of $\Sigma$ PCBs in fourteen UK sludges. The

261 concentrations were similar to the studies conducted in the Nineties, as well as the

262 Eighties and ranged between 110 and $440 \mu \mathrm{g} \mathrm{kg}^{-1}$ DS (Stevens et al., 2003).

263 Since 1998, the concentration of PCBs in sewage sludge and other environmental

264 matrices has commonly been measured following the inclusion of "dioxin-like" PCBs

265 into World Health Organisation dioxin toxicity equivalence scheme (Van den Berg et

266 al., 1998). For example, the concentrations of the three most toxic coplanar PCB

267 congeners $(77,126,169)$ as well as 7 mono-and di-ortho-PCBs (PCB 8, 28, 52, 101,

$268118,153,138,180)$ were measured in nineteen sewage sludges from Switzerland.

269 The sum of the seven mono- and di-ortho-PCBs, which are routinely measured as

270 representatives of the PCB fraction, reached levels between $43-550 \mu \mathrm{g} \mathrm{kg}^{-1} \mathrm{DS}$

271 (Berset \& Holzer, 1996). Sludges that received industrial effluents clearly showed 
higher PCB levels than rural ones (Berset \& Holzer, 1996). The concentrations of

273 'dioxin-like PCBs' will not be further summarised within this literature review as this

274 information is available in a review of dioxin-like compounds in sewage sludge

275 (Clarke et al., 2008).

276 By the new millennium, the concentration of PCBs in sludge globally had decreased

277 to be typically lower than $500 \mu \mathrm{g} \mathrm{kg}^{-1} \mathrm{DS}$. For example, in a 2003 survey of Canadian

278 sludges $(\mathrm{n}=20)$, PCBs were not detected $\left(\mathrm{dl}=50 \mu \mathrm{g} \mathrm{kg}^{-1} \mathrm{DS}\right)$ in any of the samples

279 (Bright \& Healey, 2003).

280 A survey of Spanish sludges ( $\mathrm{n}=139)$ from twenty WWTPs reported low PCB

281 concentraton ranging between 3 and $60 \mu \mathrm{g} \mathrm{kg}^{-1} \mathrm{DS}$ (Abad et al., 2005). This is well

282 below the European recommended limit of $800 \mu \mathrm{g} \mathrm{kg}^{-1} \mathrm{DS}$ for sewage sludge

283 beneficial reuse. In fact all European studies from this time had concentrations lower

284 than the European recommended contaminant limit (800 $\left.\mu \mathrm{g} \mathrm{kg}^{-1} \mathrm{DS}\right)$. A 2004 French

285 study reported PCB concentrations ranging from $70-650 \mu \mathrm{g} \mathrm{kg}^{-1} \mathrm{DS}$ in sludge

286 samples taken in a WWTP which drains the Paris area (Blanchard et al., 2004) and a

2872004 Greek study reported PCB sludge concentrations ranging between 185 and 765

$288 \mu \mathrm{g} \mathrm{kg}^{-1} \mathrm{DS}$ (Katsoyiannis \& Samara, 2004).

289 A summary of the concentration of PCBs in sewage sludges globally is presented in

290 Table 2, showing that PCBs levels have declined since measurements were begun.

291 The highest reported concentrations of PCBs in sludges occurred in the USA

$292\left(1,700,000 \mu \mathrm{g} \mathrm{kg}^{-1}\right.$ DS $)$ in 1977 and are significantly higher than PCBs in other later

293 reported sludge samples and may demonstrate the positive effect of banning these

294 chemicals. There is little variation of PCB sludge concentrations when comparing

295 countries, suggesting that PCB contamination was similar throughout developed

296 countries. Presently, PCB concentrations rarely exceed 1,000 $\mu \mathrm{g} \mathrm{kg}^{-1} \mathrm{DS}$.

297 TABLE 2 NEAR HERE

298 Few studies have investigated the origins of PCBs in wastewater treatment facilities.

299 Many European countries do not have separate sewerage and stormwater drainage

300 systems. It is hypothesized that the atmospheric deposition of PCBs is likely to

301 contribute to PCB levels in sewage sludge. The concentration of PCBs $(\Sigma 6)$ in two

302 Swedish sludge samples was measured, once during a rainy ( $\left.85 \mu \mathrm{g} \mathrm{kg}^{-1} \mathrm{DS}\right)$ and once 
303 during a dry period (54 $\mu \mathrm{g} \mathrm{kg}^{-1} \mathrm{DS}$ ), and Nylund et al. (1992) reported "the results

304 indicate somewhat increased concentrations of these substances during the rainy

305 period". This data suggests that the source of PCBs is facilitated by atmospheric

306 deposition by either direct contamination or through increased mobilisation from

307 runoff. Atmospheric deposition as a source of PCBs was supported by research that

308 investigated PCBs in the sewerage system in Paris, France, during 1999-2000. Of the

$30921.1 \mathrm{~kg}$ of PCBs $(\Sigma 7)$ detected in sewage sludge $17.6 \mathrm{~kg}$ was attributed to atmospheric

310 fallout, suggesting that atmospheric fallout is the dominant source of PCBs in these

311 sludges (Blanchard et al., 2004). The concentration of PCBs in the atmosphere was

312 found to be $40-500 \%$ greater in precipitation over urban areas than regional

313 background precipitation (Offenberg \& Baker, 1997). If atmospheric deposition of

314 PCBs is the dominant source of PCBs in the sewerage system then it is likely that the

315 concentration of PCBs in sewage will decrease as the atmospheric concentrations

316 decrease. Sweetman and Jones showed this to be the case for the atmosphere over

317 London in which the apparent half lives of the PCBs ranged from 2-6 years

318 (Sweetman \& Jones, 2000). Loganathan et al. (1997) also investigated the PCB

319 source attributed to wet and dry deposition, finding that contaminated street dust was

320 a major PCB source, particularly in areas that had historical contamination

321 (Loganathan et al., 1997).

\subsection{Australian Sewage Sludge Survey 2004 - 2006}

\subsubsection{Organochlorine Pesticides}

324 The summary statistics of OCP and PCBs concentrations measured in Australian

325 sewage sludge between the years 2004, 2005 and 2006 are presented in Table 3. All

326 compounds were less than $1 \mathrm{mg} \mathrm{kg}^{-1} \mathrm{DS}$, the highest contaminant limit for beneficial

327 reuse (NRMMC, 2004). The most prevalent OCPs detected in this survey of

328 Australian sewage sludge were dieldrin, chlordane and Total DDT, detected in 68\%,

$32927 \%$ and $14 \%$ of samples respectively. The maximum concentrations of dieldrin,

330 chlordane and Total DDT were $0.77,0.29$ and $0.27 \mathrm{mg} \mathrm{kg}^{-1}$ DS respectively. The

331 great majority of samples had concentrations less than the lower contaminant limit,

332 which means that according to Australian biosolids guidelines this material is suitable

333 for a wide range a beneficial reuses (with respect to these parameters). However, the

334 high frequency of detection of these compounds indicates that they are extremely 
335 persistent in the Australian environment. All the other OCPs were detected in less

336 than $3 \%$ of samples. In descending order these were: HCB (3\%), heptachlor (2\%),

337 DDD, DDT, aldrin and lindane $(<0.1 \%)$. Again, when detected, the concentrations of

338 these compounds were lower than guideline values that would prevent the beneficial

339 reuse of sewage sludge, most being below $0.2 \mathrm{mg} \mathrm{kg}^{-1} \mathrm{DS}$ (Australia's lowest

340 contaminant limit for unrestricted sewage sludge beneficial re-use). When detected,

341 they were close to the analytical detection limit of $0.01 \mathrm{mg} \mathrm{kg}^{-1} \mathrm{DS}$.

342 Dieldrin was the most prevalent OCP detected in samples from all regions of

343 Australia, at a frequency of 70,79, 40 and 33\% respectively. The higher detection

344 rates in the tropical regions may reflect the higher use of dieldrin in these areas to

345 combat termites. Aldrin was rarely detected in sewage sludge $(n=3)$; however, this is

346 due to the rapid conversion of aldrin to dieldrin once released in the environment.

347 Therefore, the burden of dieldrin in the sewage sludge is derived from both aldrin and 348 dieldrin (IPCS, 1989b).

349 Chlordane was only detected in sludges from tropical regions and again, this might be 350 a reflection of higher use in warmer climates for protection of houses against termites.

351 DDE comprises the majority of the reported 'Total DDT', while DDT and DDD are 352 rarely detected (Table 3). This is consistent with the reported breakdown of DDT to 353 DDE in the environment and WWTPs (IPCS, 1989a). Results were obtained that 354 didn't distinguish the contribution of the breakdown products to the Total DDT; 355 however, it is reasonable to assume that the contribution of Total DDT is comprised 356 primarily of DDE. All results are presented as 'Total DDT'. Total DDT varied 357 according to region, but no consistent trend can be observed. DDT and DDD were 358 only detected in sludges from one region. The presence of DDT in this sludge is 359 surprising given that DDT is expected to be converted to its metabolites in the WWTP 360 (IPCS, 1989a). This suggests that there was recent inappropriate use or disposal of 361 this compound in that area. DDT is also a contaminant in other pesticides such as 362 diclofol and this may be its source in this area, similar to that observed in the recent 363 Chinese study (Wang et al., 2007).

364 Heptachlor was detected in sludges from three WWTPs. Heptachlor is readily 365 converted in the environment to its metabolite heptachlor epoxide and may be more 366 useful to monitor for this compound. 
367 Overall HCB was detected in $4 \%$ of sludge samples from five WWTPs, all of which 368 were in the heavily populated state of New South Wales (NSW). It has been

369 previously reported that one of these WWTP receives contaminated trade waste which 370 may provide an indication of the source of contamination (Connell et al., 2002). It is 371 likely that HCB occurs in sewage sludge as a result of industrial applications and 372 formation as a by-product (i.e. pentachloronitrobenzene) rather than its historical use 373 as a pesticide.

374 To identify significant trends in the data from 2004, 2005 and 2006, an analysis of 375 variance (ANOVA) was performed on the concentrations of dieldrin, chlordane and 376 Total DDT. Significant differences were observed in the concentration of dieldrin $377(\mathrm{P}<0.001)$ and chlordane $(\mathrm{P}=0.003)$ with years, while no significant difference was 378 observed for Total DDT $(\mathrm{P}=0.157)$ and year. The concentration of Total DDT was 379 stable, with a mean concentration of $0.01 \mathrm{mg} \mathrm{kg}^{-1} \mathrm{DS}$ for the three years. No 380 consistent trends can be observed for the frequency of detection, the mean nor the 381 maximum concentrations over the three years of the study.

382 The OCPs can be categorized into three groups;

(1) Frequently detected $>5 \%$ - dieldrin, chlordane, DDE

(2) Low frequency of detection $<5 \%$ - heptachlor, HCB; and

(3) Rarely detected <1\% - DDT, DDD, aldrin, lindane.

386 The overall concentration of all these compounds was consistently low and never 387 exceeded the guideline values for beneficial reuse of sewage sludge. The low 388 frequency of detection for Group 2 and 3 compounds combined with the low 389 concentrations measured when detected, demonstrates that these compounds are not 390 ubiquitous in Australian sewage sludge. The results of this research should inform 391 future legislative requirements, where compliance monitoring frequency is reduced 392 over a period of time and compliance monitoring for certain compounds may be 393 eliminated entirely.

\subsubsection{Polychlorinated biphenyls}

395 The frequency of detection of PCBs in Australian sewage sludge between the years 3962004 and 2006 is low and declining, and the concentrations in samples in which PCBs 397 were detected were also low with over $98 \%$ of samples having PCB concentrations 
below $200 \mu \mathrm{g} \mathrm{kg}^{-1} \mathrm{DS}$. When PCBs were detected, the concentration of PCBs ranged between 20 to $410 \mu \mathrm{g} \mathrm{kg}^{-1} \mathrm{DS}$ and had a mean concentration of $260 \mu \mathrm{g} \mathrm{kg}{ }^{-1} \mathrm{DS}$. This is lower than all Australian regulations (500 $\mathrm{g} \mathrm{kg}^{-1} \mathrm{DS}$ ) and therefore, these sludges are classified as suitable for beneficial reuse (NRMMC, 2004). Statistically significant differences were observed between $\mathrm{PCB}$ concentration and year $(\mathrm{P}=0.001)$. Despite the fact that PCBs were only detected in samples from New South Wales and Queensland and from only four WWTPs, the difference between the States was not significant $(\mathrm{P}=0.509)$. While $\mathrm{PCBs}$ are not frequently detected in sewage sludge they are still contained within Australian infrastructure, and the environmental monitoring of these compounds may still be necessary until they are fully removed and safely disposed. PCBs were detected in $1.2 \%$ of the samples analysed and when detected were present at low concentrations.

\subsection{Australian Sewage Sludge Time Series - 1995 to 2006}

\subsubsection{Organochlorine Pesticides}

Presented are the OCP concentrations in sewage sludge, analysed approximately weekly at six NSW wastewater treatments plants between the years 1995 and 2006; TS1, TS2, TS3, TS4, TS5. Data from the years 2001 - 2004 have been collected from TS6. The overall summary statistics are presented in Table 4.

Dieldrin, chlordane and Total DDT (primarily DDE) were the main OCPs detected (frequency of detection 69\%, 45\% and 8\% respectively) and they were detected in each of the WWTPs, in all years. OCPs such as aldrin, DDT, DDD, HCB, and lindane were detected infrequently. Lindane was not detected in any of the 2266 sludge samples from six WWTPs between the years 1995 and 2006. Therefore, lindane is not prevalent in Australian sewage sludge from this geographical area and has not been included in the following statistical analysis. Aldrin and heptachlor were rarely detected in over ten years of analysis. Aldrin was detected in 6 of the 2266 sludges analysed $(0.26 \%)$ and heptachlor was detected in only nine $(0.40 \%)$, both with maximum concentrations below those restricting land use; aldrin max $0.41 \mathrm{mg}$ $\mathrm{kg}^{-1} \mathrm{DS}$, heptachlor $0.25 \mathrm{mg} \mathrm{kg}^{-1} \mathrm{DS}$. As a result no further discussion of these compounds will be undertaken. 
428 Dieldrin was the most prevalent compound detected in the data spanning 10 years of 429 analysis, with an overall frequency of detection of $68.6 \%$, ranging between 47.6 to $43085.0 \%$ for the individual treatment plants. The overall dieldrin concentration from 431 each of the WWTPs wasn't significantly different from one another $(\mathrm{p}=0.327)$ with 432 the means ranging between $0.03-0.10 \mathrm{mg} \mathrm{kg}^{-1} \mathrm{DS}$. A significant difference was 433 found between years $(\mathrm{p}<0.001)$ reducing from a mean concentration of $0.17 \mathrm{mg} \mathrm{kg}^{-1}$ 434 DS in 1995 to $<0.01 \mathrm{mg} \mathrm{kg}^{-1}$ DS in 2006. A statistically significant linear regression 435 ( $\mathrm{p}<0.001)$ was obtained that estimates the reduction of dieldrin concentration to be $4360.0151 \mathrm{mg} \mathrm{year}^{-1}$ and it is estimated that dieldrin concentration in freshly generated 437 Australian sludges has a half life of 5.6 years. Factors that will influence the 438 concentration of dieldrin in sewage sludge are the quantities released into the 439 surrounding environment, the mechanisms involved in its environmental transport and 440 its environmental degradation rate. It has taken greater than 11.9 years following 441 Australian government restrictions, implemented in 1992, for the concentrations of 442 dieldrin in freshly generated sewage sludge to reduce to below detection limits $(<0.01$ $\left.443 \mathrm{mg} \mathrm{kg}^{-1} \mathrm{DS}\right)$.

444 Chlordane was the next most frequently detected compound, detected in $45 \%$ of 445 samples. The overall mean concentration was $0.11 \mathrm{mg} \mathrm{kg}^{-1} \mathrm{DS}$ and ranged from $446<0.01$ to $0.73 \mathrm{mg} \mathrm{kg}^{-1} \mathrm{DS}$. There was no significant difference between the chlordane 447 concentration and WWTP mean $(\mathrm{p}=0.729)$ but there was a difference between years 448 ( $\mathrm{p}<0.001)$, reducing from $0.17 \mathrm{mg} \mathrm{kg}^{-1} \mathrm{DS}$ in 1995 to $<0.01 \mathrm{mg} \mathrm{kg}^{-1} \mathrm{DS}$ in 2006. A 449 statistically significant linear regression $(\mathrm{p}<0.001)$ was performed that estimates the 450 chlordane concentration to be declining by $0.0181 \mathrm{mg} \mathrm{year}^{-1}$ and has an estimated 451 half-life of 4.7 years. It has taken at least 10.5 years for the concentration of 452 chlordane in freshly generated Australian sewage sludge to reduce to less than 453 detectable concentrations $\left(<0.01 \mathrm{mg} \mathrm{kg}^{-1} \mathrm{DS}\right)$ following government restriction 454 introduced in 1995.

455 The frequency of detection of Total DDT was lower than in the collated data survey. 456 While Total DDT was found in 7.7\% of samples, DDT, DDD and DDE were detected 457 in only $1.3,3.9$ and $5.7 \%$ of samples. Similar to the collated data, DDE was the most 458 prevalent of the DDTs, with the exception of WWTP TS6. At TS6, both DDT and 459 DDD were detected in 4.6 and $15.8 \%$ of samples respectively. This finding is 460 unusual and suggests that DDT was being used within the area or that DDT had been 
461 recently released as a by-product of other pesticides such as dicofol. DDT and DDD

462 were rarely detected in samples from the other WWTPs, which is similar to the data

463 from the collation of Australian OCP sewage sludge concentrations (2004 - 2006)

464 survey.

465 The concentration of Total DDT was significantly different between WWTPs ( $<$

466 0.001) ranging from 0.01 to $0.04 \mathrm{mg} \mathrm{kg}^{-1} \mathrm{DS}$. Total DDT concentration was also

467 significantly different between years $(\mathrm{p}<0.001)$, peaking in 1996 with a mean of 0.07

$468 \mathrm{mg} \mathrm{kg}^{-1} \mathrm{DS}$ and declining to $<0.01 \mathrm{mg} \mathrm{kg}^{-1} \mathrm{DS}$ in 2006.

469 The concentrations of dieldrin and chlordane in sewage sludge generated from each of 470 the WWTP analysed between the years 1995 and 2006 were all highly correlated ( $\mathrm{p}$ 471 0.05). The other feature that is apparent is the change in detection limit between 1995 $4722001\left(\mathrm{dl}=0.1 \mathrm{mg} \mathrm{kg}^{-1} \mathrm{DS}\right)$ and $2001-2006\left(\mathrm{dl}=0.01 \mathrm{mg} \mathrm{kg}^{-1} \mathrm{DS}\right)$. The lower 473 frequency of detection (88\% and 97\% detection of dieldrin and chlordane in 2006 474 reducing to $69 \%$ and $22 \%$ in 2006 respectively) and the statistical methodology 475 employed (i.e. treating < $\mathrm{dl}$ as half the detection limit) combine so that the mean 476 concentrations are lower when comparing the two periods. Given that the sampling 477 events did not occur on the same day or with the same frequency the statistical 478 analysis of this data is problematic. Treatment of samples less than the detection limit 479 will also affect the quality of the statistical analysis. Regardless of the statistical 480 approach undertaken the trend observed is consistent. Values below the detection 481 limit treated as missing data (*) amplify the apparent concentration and does not 482 utilize all the available information. Treating values below the detection limit as zero 483 is also unrealistic, particularly with respect to changes in the detection limit in 2001. 484 Treating values below the detection limit as half the detection limit was seen as the 485 best approach as it incorporates this data into the overall average.

486 The analytical approach was to create a categorical variable of month-year using half 487 the detection limit. All samples were analysed at the same laboratory and the change 488 in detection limit occurred simultaneously for all WWTPs. Using this categorical 489 variable, it was determined that not only are the concentrations of dieldrin and 490 chlordane correlated within each of the WWTPs, they are also correlated between the 491 respective WWTPs $(\mathrm{P}<0.05)$ (Figure 1). This work provides clear evidence that 492 dieldrin and chlordane have moved in same way from the environment and into the 493 WWTPs. Within Australia, both these compounds were primarily used on wood in 
494 domestic properties for the treatment of termites. The correlation between the rainfall

495 and concentration was tested and no correlation was established.

496

497

498

499

500

501

502

503

504

505

506

507

508

509

510

511

512

\subsubsection{Polychlorinated Biphenyls}

The concentration of PCBs in sewage sludge was measured approximately weekly at six WWTPs from the same geographic region (radius $100 \mathrm{~km}$ ) between the years 1995 and 2006 (TS1-TS5) and another WWTP between the years 2001 - 2004 (TS6). The overall summary statistics are presented in Table 4.

PCBs were detected in four of the six WWTPs and at a much greater frequency in TS5 (16.0\%) and TS1 (11.0\%) than the other WWTPs or determined as part of the 2004 - 2006 data collation survey. PCBs were not detected in two WWTPs (TS2, TS6) and detected at low frequency in the remaining two (TS3, TS4). A correlation analysis was performed to determine if a relationship existed between PCB concentrations and WWTPs, but no correlation was observed. Overall, the mean and maximum concentration decreases with time. When PCBs were detected in sewage sludge it was usually below Australian regulatory levels for beneficial reuse. Only ten samples out of $2266 \mathrm{had}$ concentrations that exceeded the guideline value of $500 \mu \mathrm{g}$ $\mathrm{kg}^{-1}$ DS, Figure 2a (NRMMC, 2004).

While no statistical correlation was determined between PCB concentrations and WWTP, two PCB spikes occurred. The first spike in PCB concentration occurred simultaneously between September 1999 to August 2000 in WWTPs TS1 and TS5 for approximately 1 year (Figure 2a Mean PCB concentrations ( $\mu \mathrm{g} \mathrm{kg}^{-1} \mathrm{DS}$ ) at six NSW WWTPs (between the years 1995 and 2006) from the same geographic region. Error bars represent maximum and minimum concentrations observed; if the mean was less than detection limit then this value has been used for graphical purposes. Red lines represent Australian (500 $\mu \mathrm{g} \mathrm{kg}^{-1} \mathrm{DS}$ ) and European (800 $\mu \mathrm{g} \mathrm{kg}^{-1} \mathrm{DS}$ ) polychlorinated biphenyl contaminant limit (European Commission, 2001; NRMMC, 2004).

Figure 2b). Since these WWTPs are approximately $100 \mathrm{~km}$ apart, it is possible that PCBs were released into the local environment during this period or that PCBs were inappropriately disposed of into the sewerage system. The length of time (1 year) taken for PCBs to fall below the detection limit may provide some indication of the time taken for PCBs to be depurated from the environment, once released. A second smaller spike in concentration appears at three WWTPs (TS1, TS5, TS4) all occurring 
526 in 2002. The time of PCB occurrence and duration was more variable than the first

527 PCB spike (Figure 2b).

528 4. CONCLUSION

529 Dieldrin, chlordane and DDE were frequently detected in Australian sewage sludges

$530(\mathrm{n}=829)$ between 2004 and 2006. They were detected in 68\%, 27\% and $13 \%$ of

531 samples at maximum concentrations of $0.77,0.29$ and $0.27 \mathrm{mg} \mathrm{kg}^{-1} \mathrm{DS}$, respectively.

532 Many other OCPs were rarely detected and lindane was not detected in any samples in

533 this survey, including in analysis of sludge over ten years from six WWTPs $(n=2266)$.

534 Again, in sludges monitored for OCPs and PCBs generated from 6 WWTPs of the

535 same geographic region between 1995 and 2006, dieldrin and chlordane were the

536 most common compounds detected. Other compounds such as lindane, aldrin HCB,

537 heptachlor, DDT and DDD were rarely detected. PCBs were detected in $5.6 \%$ of

538 samples and only ten were above the threshold of $0.50 \mathrm{mg} \mathrm{kg}^{-1}$ DS limit preventing

539 beneficial reuse. A statistically significant correlation $(\mathrm{P}<0.05)$ was found between

540 the concentration of dieldrin and chlordane in sludges from each WWTP, as well as,

541 between WWTPs of the same geographic region. This study has demonstrated that

542 dieldrin and chlordane have moved from the environment into WWTP in the same

543 way and likely as a result of the same environmental influence ie., temperature,

544 rainfall, air pressure. It has taken more than 10 years for dieldrin and chlordane to

545 reduce to less than detectable concentrations in freshly generated sewage sludge in

546 Australia following government restrictions.

547 This research demonstrates OCPs and PCBs are no longer causing significant

548 contamination of Australian sewage sludge. Of the OCPs that were regularly

549 detected, the concentrations and frequency of detection have been declining since

550 1995. Given this, there is a case for reviewing the necessity of compliance

551 monitoring for these compounds in sewage sludge when destined for beneficial re-

552 use. The authors suggest that the frequency of compliance monitoring for OCPs and

553 PCBs can be reduced and phased out over a five to ten-year period.

\section{5. REFERENCES} agricultural purposes. Chemosphere, 61, 1358. 
ALCOCK, R. E. \& JONES, K. C. (1993) Polychlorinated biphenyls in digested UK sewage sludges. Chemosphere, 26, 2199.

BERGH, A. K. \& PEOPLES, R. S. (1977) Distribution of polychlorinated biphenyls in a municipal wastewater treatment plant and environs. Science of The Total Environment, 8, 197-204.

BERSET, J. D. \& HOLZER, R. (1996) Determination of coplanar and ortho substituted PCBs in some sewage sludges of Switzerland using HRGC/ECD and HRGC/MSD. Chemosphere, 32, 2317-2333.

BIRKETT, J., J. LESTER (2003) Endocrine Disrupters in Wastewater and Sludge Treatment Processes, Lewis Publishers.

BLANCHARD, M., TEIL, M. J., OLLIVON, D., LEGENTI, L. \& CHEVREUIL, M. (2004) Polycyclic aromatic hydrocarbons and polychlorobiphenyls in wastewaters and sewage sludges from the Paris area (France). Environmental Research, 95, 184-197.

BRIGHT, D. A. \& HEALEY, N. (2003) Contaminant risks from biosolids land application: Contemporary organic contaminant levels in digested sewage sludge from five treatment plants in Greater Vancouver, British Columbia. Environmental Pollution, 126, 39-49.

BUISSON, R. S. K., KIRK, P. W. W., LESTER, J. N. \& CAMPBELL, J. A. (1986) Behaviour of selected chlorinated organic micropollutants during batch anaerobic digestion. Water Pollution Control 85, 387-394.

CHENIER, P. J. (2002) Pesticides. Survey of Industrial Chemistry - Topics in Applied Chemistry. Third ed., Kluwer Academic/Plenum Publishers.

CLARKE, B., PORTER, N., SYMONS, R., BLACKBEARD, J., ADES, P. \& MARRIOTT, P. (2008) Dioxin-like compounds in Australian sewage sludge Review and national survey. Chemosphere, 72, 1215-1228.

CONNELL, D. W., MILLER, G. \& ANDERSON, S. (2002) Chlorohydrocarbon pesticides in the Australian marine environment after banning in the period from the 1970s to 1980s. Marine Pollution Bulletin, 45, 78-83.

ERICKSON, M. D. (1997) Analytical Chemistry of PCBs, Lewis Publishers.

EUROPEAN COMMISSION (2001) Organic Contaminants in Sewage Sludge For Agricultural Use. IN LANGENKAMP, H. \& PART, P. (Eds.). European Commission Joint Research Centre Institute for Environment and Sustainability Soil and Waste Unit.

FROST, P., CAMENZIND, R., MAGERT, A., BONJOUR, R. \& KARLAGANIS, G. (1993) Organic micropollutants in Swiss sewage sludge. Journal of Chromatography A, 643, 379-388.

FURR, A. K., LAWRENCE, A. W., TONG, S. S. C., GRANDOLFO, M. C., HOFSTADER, R. A., BACHE, C. A., GUTENMANN, W. H. \& LISK, D. J. (1976) Multielement and chlorinated hydrocarbon analysis of municipal sewage sludges of American cities. Environmental Science \& Technology, 10, 683-687.

GUTENMANN, W. H., RUTZKE, M., KUNTZ, H. T. \& LISK, D. J. (1994) Elements and polychlorinated biphenyls in sewage sludges of large cities in the United States. Chemosphere, 28, 725-728.

HARDEN, F., MULLER, J. \& TOMS, L. (2005) Organochlorine Pesticides (OCPs) and Polybrominated Diphenyl Ethers (PBDEs) in the Australian Population: Levels in Human Milk Environment Protection and Heritage Council of Australia and New Zealand, Canberra. 
IPCS (1989a) Environmental Health Criteria 83: DDT and its Derivatives Environmental Aspects International Programme on Chemical Safety, IPCS (1989b) Environmental Health Criteria 91: Aldrin and Dieldrin International Programme on Chemical Safety, Geneva. $<$ http://www.inchem.org/documents/ehc/ehc/ehc91.htm>

JENSEN, S. (1972) The PCB story. Ambio, 1, 123-131.

KATSOYIANNIS, A. \& SAMARA, C. (2004) Persistent organic pollutants (POPs) in the sewage treatment plant of Thessaloniki, northern Greece: occurrence and removal. Water Research, 38, 2685.

KIPOPOULOU, A. M., ZOUBOULIS, A., SAMARA, C. \& KOUIMTZIS, T. (2004) The fate of lindane in the conventional activated sludge treatment process. Chemosphere, 55, 81-91.

LOGANATHAN, B. G., IRVINE, K. N., KANNAN, K., PRAGATHEESWARAN, V.\& SAJWAN, K. S. (1997) Distribution of selected PCB congeners in the Babcock Street sewer district: A Multimedia approach to identify PCB sources in combined sewer overflows (CSOs) discharging to the Buffalo River, New York. Archives of Environmental Contamination and Toxicology, 33, 130-140. MCGRATH, D., POSTMA, L., MCCORMACK, R. J. \& DOWDALL, C. (2000) Analysis of Irish sewage sludges: Suitability of sludge for use in agriculture. Irish Journal of Agricultural and Food Research, 39, 73-78.

MCINTYRE, A. \& LESTER, J. (1984) Occurrence and distribution of persistent organochlorine compounds in U.K. sewage sludges. Water, Air, \& Soil Pollution, 23, 397-415.

MCINTYRE, A. E. \& LESTER, J. N. (1982) Polychlorinated biphenyl and organochlorine insecticide concentrations in forty sewage sludges in England. Environmental Pollution Series B, Chemical and Physical, 3, 225-230.

MUMMA, R. O., RAUPACH, D. C., WALDMAN, J. P., TONG, S. S. C., JACOBS, M. L., BABISH, J. G., HOTCHKISS, J. H., WSZOLEK, P. C., GUTENMAN, W. H., BACHE, C. A. \& LISK, D. J. (1984) National survey of elements and other constituents in municipal sewage sludges. Archives of Environmental Contamination and Toxicology, 13, 75-83.

NRMMC (2004) National Water Quality Management Strategy - Guidelines for Sewerage Systems: Biosolids Management Natural Resource Management Ministerial Council, Department of the Environment and Water Resources, Australian Government, Canberra.

NYLUND, K., ASPLUND, L., JANSSON, B., JONSSON, P., LITZEN, K. \& SELLSTROM, U. (1992) Analysis of some polyhalogenated organic pollutants in sediment and sewage sludge. Chemosphere, 24, 1721-1730.

OFFENBERG, J. H. \& BAKER, J. E. (1997) Polychlorinated biphenyls in Chicago precipitation: Enhanced wet deposition to near-shore Lake Michigan. Environmental Science \& Technology, 31, 1534-1538.

OTTAVIANI, M., CREBELLI, R., FUSELLI, S., LAROCCA, C. \& BALDASSARRI, L. T. (1993) Chemical and mutagenic evaluation of sludge from a large wastewater treatment plant. Ecotoxicology and Environmental Safety, 26, 18-32.

STEVENS, J. L., NORTHCOTT, G. L., STERN, G. A., TOMY, G. T. \& JONES, K. C. (2003) PAHs, PCBs, PCNs, organochlorine pesticides, synthetic musks, and polychlorinated n-alkanes in U.K. sewage sludge: Survey results and implications. Environmental Science \& Technology, 37, 462-467. 
SWEETMAN, A. J. \& JONES, K. C. (2000) Declining PCB concentrations in the U.K. atmosphere: Evidence and possible causes. Environmental Science \& Technology, 34, 863-869.

UNEP (2001) Stockholm Convention of Persistent Organic Pollutants United Nations Environment Programme, Stockholm, Sweden.

VAN DEN BERG, M., BIRNBAUM, L., BOSVELD, A. T. C., BRUNSTROM, B., P.COOK, FEELY, M., GIESY, J. P., HANBERG, A., HASEGAWA, R., KENNEDY, S. W., KUBIAK, T., LARSEN, J. C., LEEUWEN, F. X. R. C., LIEM, A. K. D., NOLT, C., PETERSON, R. E., POELLINGER, L., SAFE, S., SCHRENK, D., TILLITT, D., TYSKLIND, M., YOUNES, M., WAERN, F. \& ZACHAREWSKI, T. (1998) Toxic equivalency factors (TEFs) for PCBs, PCDDs, PCDFs for humans and wildlife. Environmental Health Perspectives, 106.

VAN LUIN, A. B. \& VAN STARKENBURG, W. (1984) Hazardous substances in waste water. Water Science and Technology, 17, 843-853.

WANG, Y., ZHANG, Q., LV, J., LI, A., LIU, H., LI, G. \& JIANG, G. (2007) Polybrominated diphenyl ethers and organochlorine pesticides in sewage sludge of wastewater treatment plants in China. Chemosphere, 68, 1683-1691.

WEBBER, M. D., ROGERS, H. R., WATTS, C. D., BOXALL, A. B. A., DAVIS, R. D. \& SCOFFIN, R. (1996) Monitoring and prioritisation of organic contaminants in sewage sludges using specific chemical analysis and predictive, non-analytical methods. Science of The Total Environment, 185, 27-44.

WEST, R. H. \& HATCHER, P. G. (1980) Polychlorinated biphenyls in sewage sludge and sediments of the New York Bight. Marine Pollution Bulletin, 11, 126-129.

ZITKO, V. (2003) Chlorinated Pesticides: Aldrin, DDT, Endrin, Dieldrin, Mirex. Persistent Organic Pollutants. 
Table 1 Concentration of OCPs in international sewage sludge as reported in the scientific literature $\mu \mathrm{g}$ $\mathrm{kg}^{-1} \mathrm{DS}$

\begin{tabular}{|c|c|c|c|c|c|}
\hline $\begin{array}{l}\text { Country Year } \\
\text { Method }\end{array}$ & Analyte & $\begin{array}{l}\text { Range } \\
\mu g_{k^{-1}} \mathrm{DS}\end{array}$ & $\begin{array}{l}\text { Mean } \\
\mu \mathrm{g} \mathrm{kg}^{-1} \mathrm{DS}\end{array}$ & $\begin{array}{l}\text { Median } \\
\mu \mathrm{g} \mathrm{kg}^{-1} \mathrm{DS}\end{array}$ & Reference \\
\hline $\begin{array}{l}\text { USA } 1976 \\
\text { (GC-ECD) }\end{array}$ & Dieldrin & $<0.03-2.2$ & 0.19 & 0.27 & $\begin{array}{l}\text { (Furr et al., } \\
1976 \text { ) }\end{array}$ \\
\hline $\begin{array}{l}\text { UK } 1982 \\
(\mathrm{GC}-\mathrm{ECD})\end{array}$ & $\begin{array}{l}\text { DDE } \\
\text { Dieldrin } \\
\text { Lindane }\end{array}$ & $\begin{array}{l}<10-49 \\
<10-1260 \\
<10-930\end{array}$ & $\begin{array}{l}20 \\
280 \\
210\end{array}$ & $\begin{array}{l}40 \\
260 \\
180\end{array}$ & $\begin{array}{l}\text { (McIntyre \& } \\
\text { Lester, 1982) }\end{array}$ \\
\hline $\begin{array}{l}\text { UK } 1984 \\
\text { (GC-ECD) }\end{array}$ & $\begin{array}{l}\text { Aldrin } \\
\text { Dieldrin } \\
\text { Lindane }\end{array}$ & $\begin{array}{l}<10-90,210 \\
<10-52,940 \\
<10-70,000\end{array}$ & $\begin{array}{l}30 \\
500 \\
410\end{array}$ & $\begin{array}{l}20 \\
130 \\
90\end{array}$ & $\begin{array}{l}\text { (McIntyre \& } \\
\text { Lester, 1984) }\end{array}$ \\
\hline Netherlands 1984 GC-ECD & $\begin{array}{l}\mathrm{HCB} \\
\text { Lindane }\end{array}$ & $\begin{array}{l}<50-650 \\
<50-80\end{array}$ & $\begin{array}{l}360 \\
*\end{array}$ & $\begin{array}{l}360 \\
<50\end{array}$ & $\begin{array}{l}\text { (van Luin \& } \\
\text { van } \\
\text { Starkenburg, } \\
1984 \text { ) }\end{array}$ \\
\hline $\begin{array}{l}\text { Switzerland } 1993 \\
\text { GC-MS, GC-ECD }\end{array}$ & $\begin{array}{l}\text { HCB } \\
\text { Lindane } \\
\text { Total DDT }\end{array}$ & $\begin{array}{l}\text { nd }-144 \\
\text { nd }-118 \\
\text { nd }-376\end{array}$ & $\begin{array}{l}21 \\
21 \\
70\end{array}$ & $\begin{array}{l}\text { nd } \\
\text { nd } \\
70\end{array}$ & $\begin{array}{l}\text { (Frost et al., } \\
\text { 1993) }\end{array}$ \\
\hline $\begin{array}{l}\text { Italy } 1993 \\
\text { (HRGC-MS) }\end{array}$ & $\begin{array}{l}\text { DDE } \\
\text { DDE } \\
\text { HCB }\end{array}$ & $\begin{array}{l}20-90 \\
5-20 \\
10-305\end{array}$ & $\begin{array}{l}49 \\
12.5 \\
89\end{array}$ & $\begin{array}{l}30 \\
12.5 \\
10-305\end{array}$ & $\begin{array}{l}\text { (Ottaviani et al., } \\
\text { 1993) }\end{array}$ \\
\hline $\begin{array}{l}\text { Canada } 1996 \\
\text { (HRGC-MS) }\end{array}$ & $\begin{array}{l}\text { DDE } \\
\text { HCB }\end{array}$ & $\begin{array}{l}<10-13 \\
<10-33\end{array}$ & * & $\begin{array}{l}<10 \\
1\end{array}$ & $\begin{array}{l}\text { (Webber } \text { et al., } \\
\text { 1996) }\end{array}$ \\
\hline & \multicolumn{4}{|c|}{ Aldrin, chlordane, heptachlor, DDT were below the detection limit $(<10)$} & \\
\hline $\begin{array}{l}\text { Ireland } 2000 \\
\text { GC-ECD }\end{array}$ & DDE & $<10-106$ & 51 & 5 & \multirow{2}{*}{$\begin{array}{l}\text { (McGrath et al., } \\
2000) \\
\text { (Stevens et al., } \\
2003 \text { ) }\end{array}$} \\
\hline $\begin{array}{l}\text { UK } 2003 \\
\text { (HRGC-LRMS) }\end{array}$ & $\begin{array}{l}\text { DDE } \\
\mathrm{HCB}\end{array}$ & $\begin{array}{l}6.0-28 \\
6.4-28\end{array}$ & $\begin{array}{l}13 \\
42\end{array}$ & $\begin{array}{l}13 \\
22\end{array}$ & \\
\hline & \multicolumn{4}{|c|}{ Lindane, DDT, DDD, chlordane were "low or at non-detectable levels" } & \\
\hline $\begin{array}{l}\text { Greece } 2004 \\
\text { (HRGC-LRMS) }\end{array}$ & $\begin{array}{l}\text { DDE } \\
\text { DDD } \\
\text { Dieldrin } \\
\text { Heptachlor }\end{array}$ & $\begin{array}{l}<\mathrm{dl}-96 \\
<\mathrm{dl}-400 \\
<\mathrm{dl}-86 \\
<\mathrm{dl}-170\end{array}$ & $\begin{array}{l}27 \\
78 \\
15 \\
41\end{array}$ & $\begin{array}{l}19 \\
130 \\
<\mathrm{dl} \\
<\mathrm{dl}\end{array}$ & $\begin{array}{l}\text { (Katsoyiannis \& } \\
\text { Samara, 2004) }\end{array}$ \\
\hline $\begin{array}{l}\text { China } 2007 \\
\text { (HRGC-HRMS) }\end{array}$ & $\begin{array}{l}\text { DDE } \\
\text { DDT } \\
\text { HCB } \\
\text { Lindane }\end{array}$ & $\begin{array}{l}10.5-730.3 \\
<0.10-100.7 \\
7.5-318.7 \\
<0.04-7.4\end{array}$ & $\begin{array}{l}142.8 \\
10.0 \\
145.3 \\
0.6\end{array}$ & $\begin{array}{l}91.2 \\
2.4 \\
133.8 \\
<0.04\end{array}$ & $\begin{array}{l}\text { (Wang et al., } \\
\text { 2007) }\end{array}$ \\
\hline
\end{tabular}

$<d l$ is used if the detection limit has not been supplied in the text 
Table 2 Concentration of PCBs in sewage sludges globally as reported in the scientific literature reported in $\mu \mathrm{g} \mathrm{kg}^{-1} \mathrm{DS}$

\begin{tabular}{|c|c|c|c|c|c|}
\hline $\begin{array}{l}\text { Country Year } \\
\text { Method }\end{array}$ & Analyte & $\begin{array}{l}\text { Range } \\
\mu \mathrm{g} \mathrm{kg}^{-1} \mathrm{DS}\end{array}$ & $\begin{array}{l}\text { Mean } \\
\mu \mathrm{g} \mathrm{kg}^{-1} \mathrm{DS}\end{array}$ & $\begin{array}{l}\text { Median } \\
\mu \mathrm{g} \mathrm{kg}^{-1} \mathrm{DS}\end{array}$ & Reference \\
\hline $\begin{array}{l}\text { USA } 1976 \\
\text { GC-ECD }\end{array}$ & Arochlor 1254 & $<10-23,000$ & 5,200 & 4,200 & (Furr et al., 1976) \\
\hline $\begin{array}{l}\text { USA } 1977 \\
\text { GC-ECD }\end{array}$ & Arochlor 1016 & $238,000-1,700,000$ & 765,000 & $*$ & $\begin{array}{l}\text { (Bergh \& Peoples, } \\
\text { 1977) }\end{array}$ \\
\hline $\begin{array}{l}\text { USA } 1980 \\
\text { GC-ECD }\end{array}$ & $\Sigma \mathrm{PCBs}$ & $1,200-6,200$ & 3,400 & 3,200 & $\begin{array}{l}\text { (West \& Hatcher, } \\
1980 \text { ) }\end{array}$ \\
\hline $\begin{array}{l}\text { UK } 1982 \\
\text { GC-ECD }\end{array}$ & Arochlor 1260 & $20-460$ & 160 & 150 & $\begin{array}{l}\text { (McIntyre \& Lester, } \\
\text { 1982) }\end{array}$ \\
\hline $\begin{array}{l}\text { UK } 1984 \text { GC- } \\
\text { ECD }\end{array}$ & Arochlor 1260 & $10-21,500$ & 340 & 140 & $\begin{array}{l}\text { (McIntyre \& Lester, } \\
1984 \text { ) }\end{array}$ \\
\hline $\begin{array}{l}\text { USA } 1984 \text { GC- } \\
\text { ECD }\end{array}$ & $\Sigma \mathrm{PCBs}$ & $150-3,600$ & 1,200 & 900 & (Mumma et al., 1984) \\
\hline $\begin{array}{l}\text { Netherlands } 1984 \\
\text { GC-ECD }\end{array}$ & $\begin{array}{l}\text { (1) PCBs (6) } \\
\text { (2) PCBs (17) }\end{array}$ & $\begin{array}{l}210-660 \\
390-1,480\end{array}$ & $\begin{array}{l}500 \\
880\end{array}$ & $\begin{array}{l}580 \\
960\end{array}$ & $\begin{array}{l}\text { (van Luin \& van } \\
\text { Starkenburg, 1984) }\end{array}$ \\
\hline $\begin{array}{l}\text { UK } 1993 \text { HRGC- } \\
\text { ECD }\end{array}$ & $\Sigma \mathrm{PCBs}$ & $106-712$ & 292 & $*$ & $\begin{array}{l}\text { (Alcock \& Jones, } \\
\text { 1993) }\end{array}$ \\
\hline $\begin{array}{l}\text { Italy } 1993 \\
\text { (HRGC-MS) }\end{array}$ & $*$ & $210-1010$ & 628 & 565 & $\begin{array}{l}\text { (Ottaviani et al., } \\
\text { 1993) }\end{array}$ \\
\hline $\begin{array}{l}\text { USA } 1994 \\
\text { (HRGC-ECD) }\end{array}$ & $\Sigma \mathrm{PCBs}$ & $<250-4600$ & $<250$ & $<250$ & $\begin{array}{l}\text { (Gutenmann et al., } \\
\text { 1994) }\end{array}$ \\
\hline $\begin{array}{l}\text { Switzerland } 1996 \\
\text { HRGC-MS }\end{array}$ & $\begin{array}{l}\text { (1) Co-planar (2) } \\
\Sigma \text { PCBs (7); 28, } \\
52,101,118,153, \\
138,180\end{array}$ & $\begin{array}{l}0.231-5.05 \\
43-550\end{array}$ & * & * & $\begin{array}{l}\text { (Berset \& Holzer, } \\
\text { 1996) }\end{array}$ \\
\hline $\begin{array}{l}\text { Canada } 1996 \\
\text { (HRGC-MS) }\end{array}$ & $\Sigma \mathrm{PCBs}$ & $<10-28$ & $*$ & $<10$ & (Webber et al., 1996) \\
\hline $\begin{array}{l}\text { Ireland } 2000 \\
\text { GC-ECD }\end{array}$ & $\Sigma \mathrm{PCBs}$ & $<10-105$ & 58 & 7 & (McGrath et al., 2000) \\
\hline $\begin{array}{l}\text { Canada } 2003 \\
\text { (HRGC-MS) }\end{array}$ & $\Sigma \mathrm{PCBs}$ & $<50$ & $*$ & $*$ & $\begin{array}{l}\text { (Bright \& Healey, } \\
\text { 2003) }\end{array}$ \\
\hline $\begin{array}{l}\text { UK } 2003 \\
\text { (HRGC-MS) }\end{array}$ & $\Sigma \mathrm{PCBs}$ & $110-440$ & $*$ & * & (Stevens et al., 2003) \\
\hline $\begin{array}{l}\text { France } 2004 \\
\text { HRGC-MS }\end{array}$ & $\Sigma \mathrm{PCBs}$ & $70-650$ & $*$ & $*$ & $\begin{array}{l}\text { (Blanchard et al., } \\
\text { 2004) }\end{array}$ \\
\hline $\begin{array}{l}\text { Greece } 2004 \\
\text { (HRGC-MS) }\end{array}$ & $\Sigma \mathrm{PCBs}$ & $180-765$ & 550 & 500 & $\begin{array}{l}\text { (Katsoyiannis \& } \\
\text { Samara, 2004) }\end{array}$ \\
\hline $\begin{array}{l}\text { Spain } 2005 \\
\text { HRGC-MS }\end{array}$ & $\Sigma$ PCBs (7) & $3-60$ & $*$ & 30 & (Abad et al., 2005) \\
\hline
\end{tabular}


Table 3 Summary statistics of OCP concentrations $\left(\mathrm{mg} \mathrm{kg}^{-1} \mathrm{DS}\right)$ in Australian sewage sludges analysed between 2004 - 2006

\begin{tabular}{|c|c|c|c|c|c|c|c|}
\hline Compound & PD & $<\mathrm{DL}$ & $f$ & $\begin{array}{c}\text { Mean } \\
\mathrm{mg} \mathrm{kg}^{-1} \text { DS }\end{array}$ & $\begin{array}{c}\text { StDev } \\
\mathrm{mg} \mathrm{kg}^{-1} \text { DS }\end{array}$ & $\begin{array}{c}\text { Median } \\
\mathrm{mg} \mathrm{kg}^{-1} \mathrm{DS}\end{array}$ & $\begin{array}{c}\text { Max } \\
\text { mg kg-1 DS }^{-1}\end{array}$ \\
\hline Aldrin & 3 & 826 & 0.4 & $<0.01$ & $<0.01$ & $<0.01$ & 0.07 \\
\hline Chlordane & 227 & 602 & 27.4 & 0.01 & 0.02 & $<0.01$ & 0.29 \\
\hline Dieldrin & 567 & 262 & 68.4 & 0.03 & 0.04 & 0.02 & 0.70 \\
\hline Heptachlor & 16 & 813 & 2.0 & $<0.01$ & $<0.01$ & $<0.01$ & 0.17 \\
\hline HCB & 22 & 807 & 2.7 & $<0.01$ & 0.01 & $<0.01$ & 0.30 \\
\hline Lindane & 0 & 829 & 0.0 & $<0.01$ & 0.00 & $<0.01$ & $<0.01$ \\
\hline DDT & 2 & 782 & 0.2 & $<0.01$ & $<0.01$ & $<0.01$ & 0.03 \\
\hline DDD & 4 & 780 & 0.5 & $<0.01$ & $<0.01$ & $<0.01$ & 0.06 \\
\hline DDE & 103 & 681 & 13.1 & $<0.01$ & 0.02 & $<0.01$ & 0.27 \\
\hline Total DDT & 112 & 717 & 13.5 & $<0.01$ & 0.02 & $<0.01$ & 0.27 \\
\hline$\Sigma$ PCBs & 10 & 819 & 1.2 & $<0.01$ & 0.03 & $<0.01$ & 410 \\
\hline
\end{tabular}

$P D=$ positive detection, $<D L=$ less than detection limit $\left(<0.01 \mathrm{mg} \mathrm{kg}^{-1} \mathrm{DS}\right), f=$ percentage frequency detection. $n=784 D D T, D D D, D D E$

$n=829$ Total DDT, Aldrin, chlordane, dieldrin, heptachlor, $\mathrm{HCH}$, lindane

693

694

695 
Table 4 Summary statistics of OCP and PCB concentrations $\left(\mathrm{mg} \mathrm{kg}^{-1} \mathrm{DS}\right)$ in Australian sewage sludge sampled from six wastewater treatments plant from the same geographic region between the years 1995 and 2006

\begin{tabular}{|c|c|c|c|c|c|c|}
\hline Variable & $f$ & $<\mathrm{DL}$ & $\begin{array}{c}\text { Mean } \\
\text { mg kg }^{-1} \text { DS }\end{array}$ & $\begin{array}{c}\text { StDev } \\
\mathrm{mg} \mathrm{kg}^{-1} \mathrm{DS}\end{array}$ & $\begin{array}{c}\text { Median } \\
\mathrm{mg} \mathrm{kg}^{-1} \mathrm{DS}\end{array}$ & $\begin{array}{c}\text { Max } \\
\text { mg kg }^{-1} \text { DS }\end{array}$ \\
\hline Aldrin & 0.26 & 2260 & 0.04 & 0.05 & $<0.01$ & 0.07 \\
\hline Dieldrin & 68.58 & 712 & $<0.01$ & $<0.01$ & 0.02 & 0.77 \\
\hline Chlordane & 44.84 & 1250 & 0.01 & 0.02 & $<0.01$ & 0.29 \\
\hline Heptachlor & 0.40 & 2257 & $<0.01$ & $<0.01$ & $<0.01$ & 0.17 \\
\hline $\mathrm{HCB}$ & 7.72 & 2091 & $<0.01$ & 0.01 & $<0.01$ & 0.30 \\
\hline Lindane & 0.00 & 2266 & $<0.01$ & 0.00 & $<0.01$ & $<0.01$ \\
\hline DDT & 1.30 & 2237 & $<0.01$ & $<0.01$ & $<0.01$ & 0.03 \\
\hline DDD & 3.93 & 2177 & $<0.01$ & $<0.01$ & $<0.01$ & 0.06 \\
\hline DDE & 5.69 & 2137 & $<0.01$ & 0.02 & $<0.01$ & 0.27 \\
\hline Total DDT & 7.68 & 2092 & $<0.01$ & 0.02 & $<0.01$ & 0.27 \\
\hline$\Sigma \mathrm{PCBs}$ & 5.6 & 2140 & 5.6 & 0.30 & 0.28 & 1.40 \\
\hline
\end{tabular}

$f=$ percentage frequency detection, $<D L=$ less than detection limit $\left(<0.01 \mathrm{mg} \mathrm{k}^{-1} \mathrm{DS}\right)$ 696

697 


\section{FIGURE CAPTIONS}

699 Figure 1 Comparison of dieldrin concentration $\mathrm{mg} \mathrm{kg}^{-1}$ DS between the years 1995 700 and 2006 at WWTP TS1, TS2, TS3, TS4 and TS5.

701 Figure 2a Mean PCB concentrations ( $\mu \mathrm{g} \mathrm{kg}^{-1} \mathrm{DS}$ ) at six NSW WWTPs (between the 702 years 1995 and 2006) from the same geographic region. Error bars represent 703 maximum and minimum concentrations observed; if the mean was less than detection 704 limit then this value has been used for graphical purposes. Red lines represent 705 Australian (500 $\left.\mu \mathrm{g} \mathrm{kg}^{-1} \mathrm{DS}\right)$ and European (800 $\left.\mu \mathrm{g} \mathrm{kg}^{-1} \mathrm{DS}\right)$ polychlorinated biphenyl 706 contaminant limit (European Commission, 2001; NRMMC, 2004).

707 Figure 2b PCB concentrations ( $\mu \mathrm{g} \mathrm{kg}^{-1} \mathrm{DS}$ ) at six Australian WWTPs between 1995 708 and 2006 from the same geographic region. Sample concentrations below detection 709 limit have not been plotted and comprise $94.4 \%$ of samples analysed.

710 


\section{6. SUPPLEMENTARY INFORMATION}

Overall summary statistics of OCPs time series

\begin{tabular}{|c|c|c|c|c|c|c|c|c|}
\hline Variable & PD & $<\mathrm{DL}$ & $f$ & $\begin{array}{c}\text { Mean } \\
\text { mg kg }^{-1} \\
\text { DS }\end{array}$ & $\begin{array}{l}\text { StDev } \\
\text { mg kg }^{-1} \\
\text { DS }\end{array}$ & $\begin{array}{c}\text { Min } \\
\text { mg kg }^{-1} \\
\text { DS }\end{array}$ & $\begin{array}{c}\text { Median } \\
\text { mg kg }^{-1} \\
\text { DS }\end{array}$ & $\begin{array}{c}\text { Max } \\
\text { mg kg }^{-1} \\
\text { DS }\end{array}$ \\
\hline \multicolumn{9}{|l|}{ TS1 } \\
\hline DDT & 2 & 460 & 0.43 & 0.11 & 0.09 & 0.04 & 0.11 & 0.17 \\
\hline DDD & 2 & 460 & 0.43 & 0.02 & 0.00 & 0.02 & 0.02 & 0.02 \\
\hline DDE & 10 & 452 & 2.16 & 0.02 & 0.02 & 0.01 & 0.02 & 0.05 \\
\hline Total DDT & 13 & 449 & 2.81 & 0.04 & 0.05 & 0.01 & 0.02 & 0.17 \\
\hline Dieldrin & 325 & 137 & 70.35 & 0.12 & 0.09 & 0.01 & 0.12 & 0.45 \\
\hline Aldrin & 0 & 462 & 0.00 & $*$ & $*$ & $*$ & $*$ & $*$ \\
\hline Chlordane & 191 & 271 & 41.34 & 0.14 & 0.11 & 0.01 & 0.12 & 0.65 \\
\hline Heptachlor & 6 & 456 & 1.30 & 0.14 & 0.06 & 0.10 & 0.11 & 0.25 \\
\hline $\mathrm{HCB}$ & 1 & 461 & 0.22 & 0.01 & $*$ & 0.01 & 0.01 & 0.01 \\
\hline Lindane & 0 & 462 & 0.00 & $*$ & $*$ & $*$ & $*$ & $*$ \\
\hline \multicolumn{9}{|l|}{$\underline{\text { TS2 }}$} \\
\hline DDT & 0 & 95 & 0.00 & $*$ & $*$ & $*$ & $*$ & $*$ \\
\hline DDD & 0 & 95 & 0.00 & * & $*$ & * & $*$ & * \\
\hline DDE & 2 & 93 & 2.11 & 0.02 & 0.01 & 0.01 & 0.02 & 0.02 \\
\hline Total DDT & 2 & 93 & 2.11 & 0.02 & 0.01 & 0.01 & 0.02 & 0.02 \\
\hline Dieldrin & 49 & 46 & 51.58 & 0.11 & 0.06 & 0.01 & 0.11 & 0.28 \\
\hline Aldrin & 0 & 95 & 0.00 & $*$ & $*$ & $*$ & $*$ & $*$ \\
\hline Chlordane & 42 & 53 & 44.21 & 0.16 & 0.09 & 0.01 & 0.14 & 0.34 \\
\hline Heptachlor & 0 & 95 & 0.00 & $*$ & $*$ & $*$ & $*$ & $*$ \\
\hline $\mathrm{HCB}$ & 0 & 95 & 0.00 & $*$ & $*$ & $*$ & $*$ & * \\
\hline Lindane & 0 & 95 & 0.00 & $*$ & $*$ & $*$ & $*$ & $*$ \\
\hline \multicolumn{9}{|l|}{$\underline{\text { TS3 }}$} \\
\hline DDT & 2 & 443 & 0.45 & 0.10 & 0.00 & 0.10 & 0.10 & 0.10 \\
\hline DDD & 2 & 443 & 0.45 & 0.02 & 0.01 & 0.01 & 0.02 & 0.02 \\
\hline DDE & 4 & 441 & 0.90 & 0.02 & 0.01 & 0.01 & 0.02 & 0.04 \\
\hline Total DDT & 8 & 437 & 1.80 & 0.04 & 0.04 & 0.01 & 0.02 & 0.10 \\
\hline Dieldrin & 212 & 233 & 47.64 & 0.12 & 0.09 & 0.01 & 0.12 & 0.49 \\
\hline Aldrin & 1 & 444 & 0.22 & 0.02 & * & 0.02 & 0.02 & 0.02 \\
\hline Chlordane & 157 & 288 & 35.28 & 0.13 & 0.09 & 0.01 & 0.13 & 0.46 \\
\hline Heptachlor & 1 & 444 & 0.22 & 0.25 & $*$ & 0.25 & 0.25 & 0.25 \\
\hline $\mathrm{HCB}$ & 1 & 444 & 0.22 & 0.03 & $*$ & 0.03 & 0.03 & 0.03 \\
\hline Lindane & 0 & 445 & 0.00 & $*$ & $*$ & $*$ & $*$ & $*$ \\
\hline
\end{tabular}




\begin{tabular}{|c|c|c|c|c|c|c|c|c|}
\hline Variable & PD & $<\mathrm{DL}$ & $f$ & $\begin{array}{c}\text { Mean } \\
\text { mg kg }^{-1} \\
\text { DS }\end{array}$ & $\begin{array}{l}\text { StDev } \\
\text { mg kg }^{-1} \\
\text { DS }\end{array}$ & $\begin{array}{c}\text { Min } \\
\text { mg kg }^{-1} \\
\text { DS }\end{array}$ & $\begin{array}{c}\text { Median } \\
\text { mg kg }^{-1} \\
\text { DS }\end{array}$ & $\begin{array}{c}\text { Max } \\
\text { mg kg }^{-1} \\
\text { DS }\end{array}$ \\
\hline DDT & 3 & 480 & 0.62 & 0.06 & 0.06 & 0.01 & 0.03 & 0.13 \\
\hline DDD & 11 & 472 & 2.28 & 0.30 & 0.35 & 0.01 & 0.13 & 1.04 \\
\hline DDE & 12 & 471 & 2.48 & 0.02 & 0.01 & 0.01 & 0.02 & 0.04 \\
\hline Total DDT & 19 & 464 & 3.93 & 0.19 & 0.30 & 0.01 & 0.04 & 1.04 \\
\hline Dieldrin & 363 & 120 & 75.16 & 0.11 & 0.09 & 0.01 & 0.11 & 0.47 \\
\hline Aldrin & 2 & 481 & 0.41 & 0.21 & 0.28 & 0.01 & 0.21 & 0.41 \\
\hline Chlordane & 242 & 241 & 50.10 & 0.13 & 0.12 & 0.01 & 0.12 & 0.67 \\
\hline Heptachlor & 0 & 483 & 0.00 & * & $*$ & * & $*$ & * \\
\hline $\mathrm{HCB}$ & 14 & 469 & 2.90 & 0.05 & 0.04 & 0.01 & 0.03 & 0.12 \\
\hline Lindane & 0 & 483 & 0.00 & $*$ & $*$ & $*$ & $*$ & * \\
\hline \multicolumn{9}{|l|}{$\underline{\text { TS5 }}$} \\
\hline DDT & 1 & 325 & 0.31 & 0.17 & $*$ & 0.17 & 0.17 & 0.17 \\
\hline DDD & 2 & 324 & 0.61 & 0.02 & 0.01 & 0.01 & 0.02 & 0.03 \\
\hline DDE & 29 & 297 & 8.90 & 0.02 & 0.02 & 0.01 & 0.01 & 0.10 \\
\hline Total DDT & 29 & 297 & 8.90 & 0.03 & 0.04 & 0.01 & 0.01 & 0.21 \\
\hline Dieldrin & 277 & 49 & 84.97 & 0.11 & 0.07 & 0.01 & 0.12 & 0.34 \\
\hline Aldrin & 2 & 324 & 0.61 & 0.03 & 0.01 & 0.02 & 0.03 & 0.04 \\
\hline Chlordane & 203 & 123 & 62.27 & 0.11 & 0.10 & 0.01 & 0.11 & 0.73 \\
\hline Heptachlor & 0 & 326 & 0.00 & * & $*$ & * & $*$ & $*$ \\
\hline $\mathrm{HCB}$ & 4 & 322 & 1.23 & 0.05 & 0.05 & 0.01 & 0.04 & 0.12 \\
\hline Lindane & 0 & 326 & 0.00 & $*$ & $*$ & $*$ & $*$ & $*$ \\
\hline \multicolumn{9}{|l|}{$\underline{\text { TS6 }}$} \\
\hline DDT & 21 & 434 & 4.62 & 0.03 & 0.02 & 0.01 & 0.02 & 0.10 \\
\hline DDD & 72 & 383 & 15.82 & 0.03 & 0.03 & 0.01 & 0.02 & 0.20 \\
\hline DDE & 72 & 383 & 15.82 & 0.02 & 0.02 & 0.01 & 0.01 & 0.13 \\
\hline Total DDT & 103 & 352 & 22.64 & 0.04 & 0.03 & 0.01 & 0.03 & 0.13 \\
\hline Dieldrin & 328 & 127 & 72.09 & 0.04 & 0.03 & 0.01 & 0.03 & 0.31 \\
\hline Aldrin & 1 & 454 & 0.22 & 0.07 & $*$ & 0.07 & 0.07 & 0.07 \\
\hline Chlordane & 181 & 274 & 39.78 & 0.02 & 0.02 & 0.01 & 0.02 & 0.21 \\
\hline Heptachlor & 2 & 453 & 0.44 & 0.05 & 0.01 & 0.04 & 0.05 & 0.06 \\
\hline $\mathrm{HCB}$ & 155 & 300 & 34.07 & 0.07 & 0.09 & 0.01 & 0.03 & 0.48 \\
\hline Lindane & 0 & 455 & 0.00 & $*$ & $*$ & $*$ & $*$ & $*$ \\
\hline
\end{tabular}

$P D=$ positive detection, $<D L=$ less than detection limit $\left(<0.01 \mathrm{mg} \mathrm{kg}^{-1} \mathrm{DS}\right), f=$ percentage frequency detection.

714

715 


\begin{tabular}{|c|c|c|c|c|c|c|c|c|c|}
\hline Variable & Year & $\mathbf{N}$ & $\mathbf{N}^{*}$ & $f$ & $\begin{array}{c}\text { Mean } \\
\text { mg kg }^{-1} \\
\text { DS }\end{array}$ & $\begin{array}{c}\text { StDev } \\
\text { mg kg }^{-1} \\
\text { DS }\end{array}$ & $\begin{array}{c}\text { Min } \\
\text { mg kg }^{-1} \\
\text { DS }\end{array}$ & $\begin{array}{l}\text { Median } \\
\text { mg kg-1 }^{-1} \\
\text { DS }\end{array}$ & $\begin{array}{c}\text { Max } \\
\text { mg kg }^{-1} \\
\text { DS }\end{array}$ \\
\hline \multirow[t]{12}{*}{ DDT } & 1995 & 0 & 85 & 0.0 & 0.05 & 0.00 & 0.05 & 0.05 & 0.05 \\
\hline & 1996 & 3 & 177 & 1.7 & 0.05 & 0.01 & 0.05 & 0.05 & 0.13 \\
\hline & 1997 & 1 & 178 & 0.6 & 0.05 & 0.01 & 0.05 & 0.05 & 0.17 \\
\hline & 1998 & 0 & 116 & 0.0 & 0.05 & 0.00 & 0.05 & 0.05 & 0.05 \\
\hline & 1999 & 1 & 142 & 0.7 & 0.05 & 0.01 & 0.05 & 0.05 & 0.17 \\
\hline & 2000 & 0 & 193 & 0.0 & 0.05 & 0.00 & 0.05 & 0.05 & 0.05 \\
\hline & 2001 & 0 & 185 & 0.0 & 0.05 & 0.01 & 0.01 & 0.05 & 0.05 \\
\hline & 2002 & 16 & 332 & 4.6 & 0.01 & 0.01 & 0.01 & 0.01 & 0.10 \\
\hline & 2003 & 6 & 369 & 1.6 & 0.01 & 0.00 & 0.01 & 0.01 & 0.07 \\
\hline & 2004 & 1 & 155 & 0.6 & 0.01 & 0.00 & 0.01 & 0.01 & 0.01 \\
\hline & 2005 & 1 & 142 & 0.7 & 0.01 & 0.00 & 0.01 & 0.01 & 0.03 \\
\hline & 2006 & 0 & 163 & 0.0 & 0.01 & 0.00 & 0.01 & 0.01 & 0.01 \\
\hline \multirow[t]{12}{*}{ DDD } & 1995 & 0 & 85 & 0.0 & 0.05 & 0.00 & 0.05 & 0.05 & 0.05 \\
\hline & 1996 & 6 & 174 & 3.3 & 0.07 & 0.10 & 0.05 & 0.05 & 1.04 \\
\hline & 1997 & 0 & 179 & 0.0 & 0.05 & 0.00 & 0.05 & 0.05 & 0.05 \\
\hline & 1998 & 0 & 116 & 0.0 & 0.05 & 0.00 & 0.05 & 0.05 & 0.05 \\
\hline & 1999 & 0 & 143 & 0.0 & 0.05 & 0.00 & 0.05 & 0.05 & 0.05 \\
\hline & 2000 & 0 & 193 & 0.0 & 0.05 & 0.00 & 0.05 & 0.05 & 0.05 \\
\hline & 2001 & 0 & 185 & 0.0 & 0.05 & 0.01 & 0.01 & 0.05 & 0.05 \\
\hline & 2002 & 51 & 297 & 14.7 & 0.01 & 0.01 & 0.01 & 0.01 & 0.20 \\
\hline & 2003 & 29 & 346 & 7.7 & 0.01 & 0.01 & 0.01 & 0.01 & 0.10 \\
\hline & 2004 & 0 & 156 & 0.0 & 0.01 & 0.00 & 0.01 & 0.01 & 0.01 \\
\hline & 2005 & 0 & 143 & 0.0 & 0.01 & 0.00 & 0.01 & 0.01 & 0.01 \\
\hline & 2006 & 3 & 160 & 1.8 & 0.01 & 0.00 & 0.01 & 0.01 & 0.02 \\
\hline \multirow[t]{12}{*}{ DDE } & 1995 & 0 & 85 & 0.0 & 0.05 & 0.00 & 0.05 & 0.05 & 0.05 \\
\hline & 1996 & 0 & 180 & 0.0 & 0.05 & 0.00 & 0.05 & 0.05 & 0.05 \\
\hline & 1997 & 1 & 178 & 0.6 & 0.05 & 0.00 & 0.05 & 0.05 & 0.05 \\
\hline & 1998 & 0 & 116 & 0.0 & 0.05 & 0.00 & 0.05 & 0.05 & 0.05 \\
\hline & 1999 & 0 & 143 & 0.0 & 0.05 & 0.00 & 0.05 & 0.05 & 0.05 \\
\hline & 2000 & 0 & 193 & 0.0 & 0.05 & 0.00 & 0.05 & 0.05 & 0.05 \\
\hline & 2001 & 2 & 183 & 1.1 & 0.05 & 0.01 & 0.01 & 0.05 & 0.05 \\
\hline & 2002 & 58 & 290 & 16.7 & 0.01 & 0.01 & 0.01 & 0.01 & 0.10 \\
\hline & 2003 & 42 & 333 & 11.2 & 0.01 & 0.01 & 0.01 & 0.01 & 0.13 \\
\hline & 2004 & 10 & 146 & 6.4 & 0.01 & 0.00 & 0.01 & 0.01 & 0.02 \\
\hline & 2005 & 2 & 141 & 1.4 & 0.01 & 0.00 & 0.01 & 0.01 & 0.01 \\
\hline & 2006 & 14 & 149 & 8.6 & 0.01 & 0.01 & 0.01 & 0.01 & 0.05 \\
\hline Total DDT & 1995 & 0 & 85 & 0.0 & 0.05 & 0.00 & 0.05 & 0.05 & 0.05 \\
\hline
\end{tabular}




\begin{tabular}{|c|c|c|c|c|c|c|c|c|c|}
\hline Variable & Year & $\mathbf{N}$ & $\mathbf{N}^{*}$ & $f$ & $\begin{array}{c}\text { Mean } \\
\text { mg kg }^{-1} \\
\text { DS }\end{array}$ & $\begin{array}{c}\text { StDev } \\
\text { mg kg-1 }^{-1} \\
\text { DS }\end{array}$ & $\begin{array}{c}\text { Min } \\
\text { mg kg }^{-1} \\
\text { DS }\end{array}$ & $\begin{array}{c}\text { Median } \\
\text { mg kg }^{-1} \\
\text { DS }\end{array}$ & $\begin{array}{c}\text { Max } \\
\text { mg kg }^{-1} \\
\text { DS }\end{array}$ \\
\hline & 1996 & 8 & 172 & 4.4 & 0.07 & 0.10 & 0.05 & 0.05 & 1.04 \\
\hline & 1997 & 1 & 178 & 0.6 & 0.05 & 0.01 & 0.05 & 0.05 & 0.21 \\
\hline & 1998 & 0 & 116 & 0.0 & 0.05 & 0.00 & 0.05 & 0.05 & 0.05 \\
\hline & 1999 & 1 & 142 & 0.7 & 0.05 & 0.01 & 0.05 & 0.05 & 0.17 \\
\hline & 2000 & 0 & 193 & 0.0 & 0.05 & 0.00 & 0.05 & 0.05 & 0.05 \\
\hline & 2001 & 2 & 183 & 1.1 & 0.05 & 0.01 & 0.01 & 0.05 & 0.05 \\
\hline & 2002 & 81 & 267 & 23.3 & 0.01 & 0.02 & 0.01 & 0.01 & 0.12 \\
\hline & 2003 & 51 & 324 & 13.6 & 0.01 & 0.02 & 0.01 & 0.01 & 0.13 \\
\hline & 2004 & 11 & 145 & 7.1 & 0.01 & 0.00 & 0.01 & 0.01 & 0.02 \\
\hline & 2005 & 2 & 141 & 1.4 & 0.01 & 0.00 & 0.01 & 0.01 & 0.04 \\
\hline & 2006 & 17 & 146 & 10.4 & 0.01 & 0.01 & 0.01 & 0.01 & 0.05 \\
\hline \multirow[t]{12}{*}{ Dieldrin } & 1995 & 75 & 10 & 88.2 & 0.17 & 0.07 & 0.05 & 0.17 & 0.45 \\
\hline & 1996 & 148 & 32 & 82.2 & 0.14 & 0.07 & 0.05 & 0.14 & 0.47 \\
\hline & 1997 & 107 & 72 & 59.8 & 0.12 & 0.07 & 0.05 & 0.11 & 0.39 \\
\hline & 1998 & 75 & 41 & 64.7 & 0.12 & 0.07 & 0.05 & 0.12 & 0.39 \\
\hline & 1999 & 89 & 54 & 62.2 & 0.12 & 0.07 & 0.05 & 0.11 & 0.34 \\
\hline & 2000 & 141 & 52 & 73.1 & 0.14 & 0.09 & 0.05 & 0.13 & 0.49 \\
\hline & 2001 & 136 & 49 & 73.5 & 0.12 & 0.08 & 0.01 & 0.12 & 0.36 \\
\hline & 2002 & 195 & 153 & 56.0 & 0.02 & 0.02 & 0.01 & 0.01 & 0.16 \\
\hline & 2003 & 274 & 101 & 73.1 & 0.03 & 0.04 & 0.01 & 0.02 & 0.31 \\
\hline & 2004 & 90 & 66 & 57.7 & 0.02 & 0.02 & 0.01 & 0.01 & 0.10 \\
\hline & 2005 & 111 & 32 & 77.6 & 0.02 & 0.02 & 0.01 & 0.02 & 0.12 \\
\hline & 2006 & 113 & 50 & 69.3 & 0.03 & 0.02 & 0.01 & 0.02 & 0.08 \\
\hline \multirow[t]{12}{*}{ Aldrin } & 1995 & 1 & 84 & 1.2 & 0.05 & 0.04 & 0.05 & 0.05 & 0.41 \\
\hline & 1996 & 0 & 180 & 0.0 & 0.05 & 0.00 & 0.05 & 0.05 & 0.05 \\
\hline & 1997 & 0 & 179 & 0.0 & 0.05 & 0.00 & 0.05 & 0.05 & 0.05 \\
\hline & 1998 & 0 & 116 & 0.0 & 0.05 & 0.00 & 0.05 & 0.05 & 0.05 \\
\hline & 1999 & 0 & 143 & 0.0 & 0.05 & 0.00 & 0.05 & 0.05 & 0.05 \\
\hline & 2000 & 0 & 193 & 0.0 & 0.05 & 0.00 & 0.05 & 0.05 & 0.05 \\
\hline & 2001 & 0 & 185 & 0.0 & 0.05 & 0.01 & 0.01 & 0.05 & 0.05 \\
\hline & 2002 & 0 & 348 & 0.0 & 0.01 & 0.00 & 0.01 & 0.01 & 0.01 \\
\hline & 2003 & 0 & 375 & 0.0 & 0.01 & 0.00 & 0.01 & 0.01 & 0.01 \\
\hline & 2004 & 1 & 155 & 0.6 & 0.01 & 0.01 & 0.01 & 0.01 & 0.07 \\
\hline & 2005 & 4 & 139 & 2.8 & 0.01 & 0.00 & 0.01 & 0.01 & 0.04 \\
\hline & 2006 & 0 & 163 & 0.0 & 0.01 & 0.00 & 0.01 & 0.01 & 0.01 \\
\hline \multirow[t]{2}{*}{ Chlordane } & 1995 & 83 & 2 & 97.6 & 0.31 & 0.15 & 0.05 & 0.28 & 0.73 \\
\hline & 1996 & 136 & 44 & 75.6 & 0.15 & 0.09 & 0.05 & 0.14 & 0.52 \\
\hline
\end{tabular}




\begin{tabular}{|c|c|c|c|c|c|c|c|c|c|}
\hline Variable & Year & $\mathbf{N}$ & $\mathbf{N}^{*}$ & $f$ & $\begin{array}{c}\text { Mean } \\
\text { mg kg }^{-1} \\
\text { DS }\end{array}$ & $\begin{array}{c}\text { StDev } \\
\text { mg kg }^{-1} \\
\text { DS }\end{array}$ & $\begin{array}{c}\text { Min } \\
\text { mg kg }^{-1} \\
\text { DS }\end{array}$ & $\begin{array}{c}\text { Median } \\
\text { mg kg }^{-1} \\
\text { DS }\end{array}$ & $\begin{array}{c}\text { Max } \\
\text { mg kg }^{-1} \\
\text { DS }\end{array}$ \\
\hline & 1997 & 74 & 105 & 41.3 & 0.08 & 0.04 & 0.05 & 0.05 & 0.26 \\
\hline & 1998 & 60 & 56 & 51.7 & 0.10 & 0.05 & 0.05 & 0.05 & 0.28 \\
\hline & 1999 & 56 & 87 & 39.2 & 0.08 & 0.04 & 0.05 & 0.05 & 0.20 \\
\hline & 2000 & 102 & 91 & 52.8 & 0.10 & 0.05 & 0.05 & 0.10 & 0.31 \\
\hline & 2001 & 80 & 105 & 43.2 & 0.08 & 0.05 & 0.01 & 0.05 & 0.28 \\
\hline & 2002 & 122 & 226 & 35.1 & 0.01 & 0.01 & 0.01 & 0.01 & 0.08 \\
\hline & 2003 & 146 & 229 & 38.9 & 0.01 & 0.03 & 0.01 & 0.01 & 0.40 \\
\hline & 2004 & 60 & 96 & 38.5 & 0.01 & 0.01 & 0.01 & 0.01 & 0.07 \\
\hline & 2005 & 61 & 82 & 42.7 & 0.01 & 0.02 & 0.01 & 0.01 & 0.10 \\
\hline & 2006 & 36 & 127 & 22.1 & 0.01 & 0.01 & 0.01 & 0.01 & 0.07 \\
\hline \multirow[t]{12}{*}{ Hepatachlor } & 1995 & 1 & 84 & 1.2 & 0.05 & 0.02 & 0.05 & 0.05 & 0.25 \\
\hline & 1996 & 0 & 180 & 0.0 & 0.05 & 0.00 & 0.05 & 0.05 & 0.05 \\
\hline & 1997 & 6 & 173 & 3.4 & 0.05 & 0.02 & 0.05 & 0.05 & 0.25 \\
\hline & 1998 & 0 & 116 & 0.0 & 0.05 & 0.00 & 0.05 & 0.05 & 0.05 \\
\hline & 1999 & 0 & 143 & 0.0 & 0.05 & 0.00 & 0.05 & 0.05 & 0.05 \\
\hline & 2000 & 0 & 193 & 0.0 & 0.05 & 0.00 & 0.05 & 0.05 & 0.05 \\
\hline & 2001 & 0 & 185 & 0.0 & 0.05 & 0.01 & 0.01 & 0.05 & 0.05 \\
\hline & 2002 & 0 & 348 & 0.0 & 0.01 & 0.00 & 0.01 & 0.01 & 0.01 \\
\hline & 2003 & 1 & 374 & 0.3 & 0.01 & 0.00 & 0.01 & 0.01 & 0.04 \\
\hline & 2004 & 1 & 155 & 0.6 & 0.01 & 0.00 & 0.01 & 0.01 & 0.06 \\
\hline & 2005 & 0 & 143 & 0.0 & 0.01 & 0.00 & 0.01 & 0.01 & 0.01 \\
\hline & 2006 & 0 & 163 & 0.0 & 0.01 & 0.00 & 0.01 & 0.01 & 0.01 \\
\hline \multirow[t]{12}{*}{$\mathrm{HCB}$} & 1995 & 0 & 85 & 0.0 & 0.05 & 0.00 & 0.05 & 0.05 & 0.05 \\
\hline & 1996 & 1 & 179 & 0.6 & 0.05 & 0.01 & 0.05 & 0.05 & 0.12 \\
\hline & 1997 & 1 & 178 & 0.6 & 0.05 & 0.01 & 0.05 & 0.05 & 0.12 \\
\hline & 1998 & 0 & 116 & 0.0 & 0.05 & 0.00 & 0.05 & 0.05 & 0.05 \\
\hline & 1999 & 0 & 143 & 0.0 & 0.05 & 0.00 & 0.05 & 0.05 & 0.05 \\
\hline & 2000 & 0 & 193 & 0.0 & 0.05 & 0.00 & 0.05 & 0.05 & 0.05 \\
\hline & 2001 & 0 & 185 & 0.0 & 0.05 & 0.01 & 0.01 & 0.05 & 0.05 \\
\hline & 2002 & 20 & 328 & 5.7 & 0.01 & 0.01 & 0.01 & 0.01 & 0.06 \\
\hline & 2003 & 130 & 245 & 34.7 & 0.03 & 0.07 & 0.01 & 0.01 & 0.48 \\
\hline & 2004 & 19 & 137 & 12.2 & 0.01 & 0.01 & 0.01 & 0.01 & 0.11 \\
\hline & 2005 & 0 & 143 & 0.0 & 0.01 & 0.00 & 0.01 & 0.01 & 0.01 \\
\hline & 2006 & 4 & 159 & 2.5 & 0.01 & 0.00 & 0.01 & 0.01 & 0.05 \\
\hline \multirow[t]{3}{*}{ Lindane } & 1995 & 0 & 85 & 0.0 & 0.05 & 0.00 & 0.05 & 0.05 & 0.05 \\
\hline & 1996 & 0 & 180 & 0.0 & 0.05 & 0.00 & 0.05 & 0.05 & 0.05 \\
\hline & 1997 & 0 & 179 & 0.0 & 0.05 & 0.00 & 0.05 & 0.05 & 0.05 \\
\hline
\end{tabular}


Summary statistics of OCPs detected at six Australian WWTP from the same geographic region between the years 1995 and 2006

\begin{tabular}{|c|c|c|c|c|c|c|c|c|c|}
\hline Variable & Year & $\mathbf{N}$ & $\mathbf{N}^{*}$ & $f$ & $\begin{array}{c}\text { Mean } \\
\text { mg kg }^{-1} \\
\text { DS }\end{array}$ & $\begin{array}{c}\text { StDev } \\
\text { mg kg-1 }^{-1} \\
\text { DS }\end{array}$ & $\begin{array}{c}\text { Min } \\
\text { mg kg }^{-1} \\
\text { DS }\end{array}$ & $\begin{array}{c}\text { Median } \\
\text { mg kg }^{-1} \\
\text { DS }\end{array}$ & $\begin{array}{c}\text { Max } \\
\text { mg kg }^{-1} \\
\text { DS }\end{array}$ \\
\hline & 1998 & 0 & 116 & 0.0 & 0.05 & 0.00 & 0.05 & 0.05 & 0.05 \\
\hline & 1999 & 0 & 143 & 0.0 & 0.05 & 0.00 & 0.05 & 0.05 & 0.05 \\
\hline & 2000 & 0 & 193 & 0.0 & 0.05 & 0.00 & 0.05 & 0.05 & 0.05 \\
\hline & 2001 & 0 & 185 & 0.0 & 0.05 & 0.01 & 0.01 & 0.05 & 0.05 \\
\hline & 2002 & 0 & 348 & 0.0 & 0.01 & 0.00 & 0.01 & 0.01 & 0.01 \\
\hline & 2003 & 0 & 375 & 0.0 & 0.01 & 0.00 & 0.01 & 0.01 & 0.01 \\
\hline & 2004 & 0 & 156 & 0.0 & 0.01 & 0.00 & 0.01 & 0.01 & 0.01 \\
\hline & 2005 & 0 & 143 & 0.0 & 0.01 & 0.00 & 0.01 & 0.01 & 0.01 \\
\hline & 2006 & 0 & 163 & 0.0 & 0.01 & 0.00 & 0.01 & 0.01 & 0.01 \\
\hline
\end{tabular}

$P D=$ positive detection, $<D L=$ less than detection limit $\left(<0.01 \mathrm{mg} \mathrm{kg}^{-1} \mathrm{DS}\right), f=$ percentage frequency detection.

716 